University of Louisville ThinkIR: The University of Louisville's Institutional Repository

Electronic Theses and Dissertations

$5-2019$

\title{
Connecting our community : collaboration and resource sharing among community gardens in Louisville, Kentucky.
}

Emily Goldstein

University of Louisville

Follow this and additional works at: https://ir.library.louisville.edu/etd

Part of the Social and Cultural Anthropology Commons

\section{Recommended Citation}

Goldstein, Emily, "Connecting our community : collaboration and resource sharing among community gardens in Louisville, Kentucky." (2019). Electronic Theses and Dissertations. Paper 3198.

https://doi.org/10.18297/etd/3198

This Master's Thesis is brought to you for free and open access by ThinkIR: The University of Louisville's Institutional Repository. It has been accepted for inclusion in Electronic Theses and Dissertations by an authorized administrator of ThinkIR: The University of Louisville's Institutional Repository. This title appears here courtesy of the author, who has retained all other copyrights. For more information, please contact thinkir@louisville.edu. 
CONNECTING OUR COMMUNITY: COLLABORATION AND RESOURCE SHARING AMONG COMMUNITY GARDENS IN LOUISVILLE, KENTUCKY

By

Emily Goldstein
B.A., University of Louisville, 2014

A Thesis

Submitted to the Faculty of the

Graduate School of the University of Louisville

in Partial Fulfillment of the Requirements

for the Degree of

Master of Science

in Interdisciplinary Studies: Sustainability

Interdisciplinary Studies

University of Louisville

Louisville, Kentucky

May 2019 
Copyright 2019 by Emily Goldstein

All rights reserved 

CONNECTING OUR COMMUNITY: COLLABORATION AND RESOURCE SHARING AMONG COMMUNITY GARDENS IN LOUISVILLE, KENTUCKY

\author{
By \\ Emily Goldstein \\ B.A. Anthropology, University of Louisville, 2014
}

A Thesis Approved on

April 19, 2019

by the following Thesis Committee:

Dr. Angela Storey

Dr. Lisa Markowitz

Dr. Lauren Heberle 


\section{DEDICATION}

This thesis is dedicated to

Mr. Robert Buchanan

and

Mrs. Carolyn Buchanan

who have changed my life for the better

by giving me incredible opportunities. 


\section{ACKNOWLEDGEMENTS}

I would like to thank my advisor, Dr. Angela Storey, for her invaluable support and guidance. I would also like to thank the other committee members, Dr. Markowitz and Dr. Heberle, for their assistance during my research. I would also like to thank Dr. Carreiro for her guidance at the beginning stages of my thesis research. And finally, I would like to express thanks to my family, including my parents, Debbie and Alan Goldstein, and my sister, Rachel Goldstein, for encouraging me and reminding me that I can overcome any challenge. 


\section{ABSTRACT \\ CONNECTING OUR COMMUNITY: COLLABORATION AND RESOURCE SHARING AMONG COMMUNITY GARDENS IN LOUISVILLE, KENTUCKY Emily Goldstein}

April 19, 2019

Louisville, Kentucky has over two dozen active community gardens which are used and maintained by various neighborhoods and organizations. This thesis determines how collaboration and resource sharing manifest in Louisville's various community gardens. Participant observation was used to select three case study sites and semi-structured interviews were conducted with garden users and managers for each site, and with supporters and funders for Louisville community gardens. I found that Louisville community gardens share three challenges, which are funding, resources, and land ownership. Community garden actors navigate these challenges by exchanging physical resources, shared labor, and knowledge across multiple scales. This thesis utilizes broad scholarship in Urban Political Ecology to explore these experiences of exchange and sharing, which show that access to resources is influenced by political-economic relations in Louisville. 


\section{TABLE OF CONTENTS}

PAGE

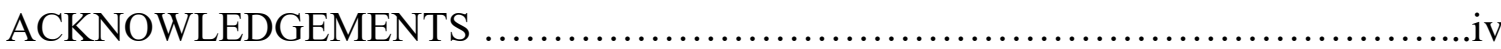

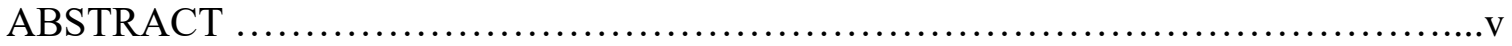

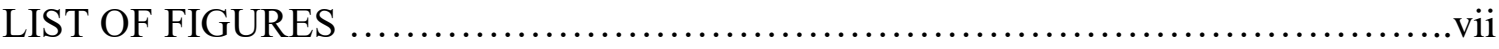

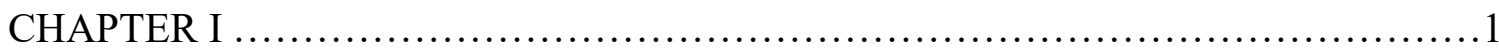

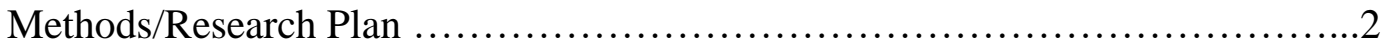

Background/Literature Review $\ldots \ldots \ldots \ldots \ldots \ldots \ldots \ldots \ldots \ldots \ldots \ldots \ldots \ldots \ldots \ldots . . \ldots \ldots$

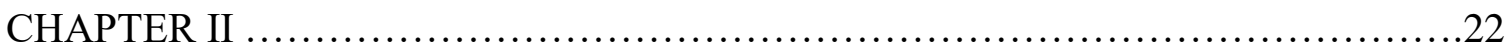

Louisville, Kentucky ................................................22

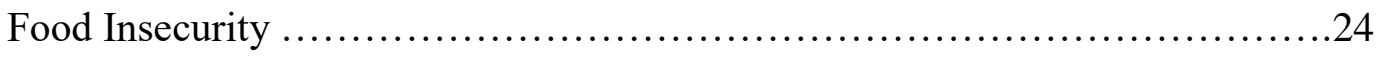

Louisville Community Gardens ......................................26

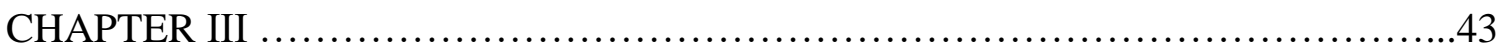

Data Analysis: Collaboration and Resource Sharing .......................45

The Urban Political Ecology of Louisville Community Gardens ..............63

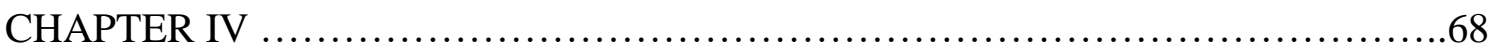

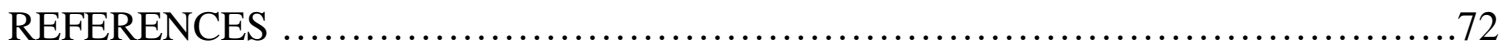

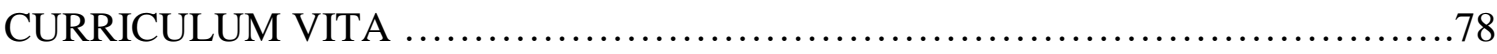




\section{LIST OF FIGURES}

FIGURE

PAGE

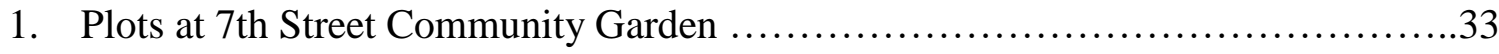

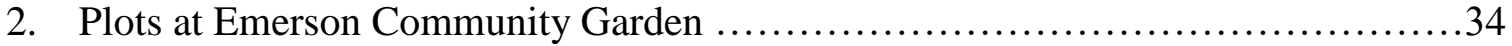

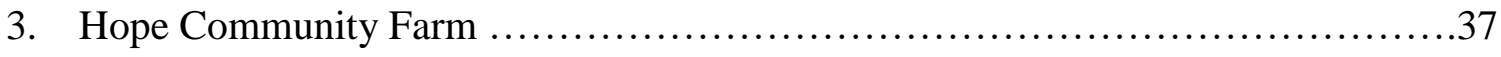

4. Parkland Community Garden's tool shed and covered shelter ...................49

5. Manure pile at Hope Community Farm ......................................5

6. Woodchip piles at 7 th Street Community Garden .............................56

7. Plots at William F. Miles Community Garden .................................60 


\section{CHAPTER I}

Community gardens have existed across America for over a century and continue to grow in popularity (Draper and Freedman 2010; Hanna and Oh 2000). Extensive research has been conducted about them around the world, often focusing on social relationships of gardeners and the communities that use the gardens (cf: Firth, Maye, and Pearson 2011; Pearsall et al. 2016) as well as examining the resources involved in garden creation and success (cf: Drake and Lawson 2014; Ghose and Pettygrove 2014). This study builds upon this broad scholarship by exploring how community gardens in Louisville, Kentucky interconnect and how these connections help them manage what little resources are available to them.

This thesis examines how collaboration and resource sharing manifest in Louisville community gardens. Louisville community gardens have diverse histories, users, and purposes, but they all share similar challenges, including finding ways to overcome funding restraints and other issues. People are meeting the challenges in creative ways such as through collaboration and resource sharing, which can occur in many ways. Resources can include physical objects, such as gardening tools and seed exchanges; information exchange, such as gardening knowledge; or shared labor. My research uses urban political ecology as a framework to analyze these topics. 
In this thesis I argue that community garden actors across multiple scales use creative forms of collaboration and resource sharing to navigate three shared challenges, which are funding, resources, and land ownership.

There were three objectives for my research, all of which I was able to meet. The first objective was to determine how many community gardens exist in Louisville. The second was to examine the key actors (e.g., property owners, managers, users, funders, etc.) involved with community garden establishment and management. The third objective was to determine what types of collaboration and resource sharing exist in Louisville community gardens, and in what forms they manifest in selected case study gardens.

In this chapter, I first explain my research methods and how my research plan changed over the course of my project. I then give a literature review on urban agriculture, community gardens, and political ecology.

\section{Methods/Research Plan}

This research utilized qualitative methods for gathering and interpreting data. The type of qualitative method was primarily ethnographic in nature. Using qualitative methods to complete this research enabled me to understand the human perspective indepth for managing and participating in community gardens (Murchison 2010; Robben and Sluka 2012). Interpreting data through qualitative methods allowed my research to be flexible, particularly when new, more case-specific questions arose from the data collected. 
Research took place in multiple phases. In Phase One of my research plan, which occurred from August through October of 2018, data collected excluded human subjects; it focused on the collection of publicly-available information about community gardens, such as that available on the Internet and via other publications. I catalogued the community gardens that were functioning in Louisville as of October 2018 and categorized them based on a set of criteria (i.e., what type of organization manages the community gardens, where they are located, etc.). These criteria were drawn from existing literature (cf: Ghose and Pettygrove 2014). Using publicly-available information such as organization websites, I identified key actors involved with Louisville's community gardens. This data helped me identify potential informants to interview in the next phase.

In Phase Two of my research, my plans changed as I ran into obstacles. During this second phase, which occurred from November 2018 through March 2019, I began my research with human subjects (University of Louisville IRB \#18.0938). Following previous research that used a case studies approach to examine the experience of community gardens (cf: Pearsall et al. 2016), I completed case studies of three Louisville community gardens. A case studies approach allowed me to gain a detailed understanding of how specific Louisville community gardens collaborate and participate in resource sharing, and how they connect to the broader landscape of work on community gardens in Louisville. These case studies were selected based on a variety of criteria in order to profile them across categories (i.e., must be at least two years old, must have a certain number of users, must be in Jefferson County, etc.). I categorized them based on what type of organization manages them (i.e., Catholic ministries, city government, and non- 
governmental organizations). I intended to select a community garden site in each major funding category for my case studies, in order to compare collaboration and resource sharing between the three organizations. Due to the obstacle of finding people to contact and, also, in realizing that community gardens run by the same organization differed, I ultimately selected two case study sites managed by Louisville Metro (the Jefferson County Extension Office) and one case study site run by Catholic ministries. I selected these three community garden sites based on the previously mentioned criteria as well as by access. For example, I was unable to find contact information for a garden manager at a garden run by a non-profit organization, but I was able to find contact information for the gardens managed by the Jefferson County Extension Office and Gate of Hope Ministries. By studying community gardens that are run by different organizations, I was able to compare how collaboration and resource sharing manifested across varied sites. Additionally, I was able to compare their access to resources (i.e., funding, seeds, knowledge).

I used semi-structured interviews for my research (Murchison 2010). Interview participants included those that run and/or manage community gardens (e.g., government employees and Catholic missionaries) in Louisville, individual community gardeners, and organizations that fund and/or support community gardens. Interviewees included those individuals directly connected to the selected case study gardens, as well as those individuals who are part of the wider network of support for community gardens and related initiatives in Louisville. I used targeted sampling to select my initial interviewees, and then used snowball sampling to determine additional interviewees. 
Interview guides were developed to identify relevant topics and questions pertaining to each interview based on type (e.g. garden managers, individual gardeners, and funders/supporters.). Interviews can bring up related topics that had not occurred to the interviewer in advance, which is why a semi-structured format was followed in formal interviews. Interviews took place where the participant was comfortable, such as in a private home, a public coffeeshop, or a work office. Interviews were recorded on a recording device and then transcribed shortly after, with notes taken in a notebook and transcribed into fieldnotes following the interview. I used jottings and short notes to help me remember the conversation and fleshed out the notes immediately after I left the field site.

Interview participants were selected based on the following criteria: they must be currently involved with community gardens in Louisville, Kentucky (falling within one of the interview categories above), and must be over eighteen years old. I planned to collect up to 36 total interviews covering individuals from three categories of people at each site: community garden users, community garden managers, and people who provide resources to community gardens. However, due to a variety of limitations, I was unable to conduct this number of interviews. Locating garden users to interview was particularly difficult; the gardens were largely inactive during the winter months, so I was unable to meet people at the gardens for interviews. I was able to find garden users to interview from various Jefferson County Extension Office community gardens by attending meetings and by leaving my contact information on community garden notice boards. I interviewed eight individuals involved with community gardens throughout Louisville: two gardeners at 7th Street, one gardener at Emerson, the garden manager at 
Hope Community Farm, the manager of all ten JCEO gardens, the program manager for Common Earth Gardens, the Urban Agriculture Conservationist at the Jefferson County Soil and Water Conservation District, and the Urban Agriculture Program Manager at Louisville Grows. My initial project goals required having interviews with multiple people at each garden at multiple levels, but my goals were revised to focus on key actors at the garden sites, in addition to including data from other community garden sites in Louisville. I interviewed the major actors involved with Louisville community garden organizations, which gave me a large amount of information to process. Ultimately, my research resulted in a smaller interview sample size than I had anticipated, many of whom represented garden-related organizations. Thus, I changed my focus to collaboration and resource exchange at the organizational level, with a minor focus on collaboration and resource exchange at the individual level. Despite the small sample size, I was able to obtain sufficient data from the major actors in Louisville community gardens and through participant observation.

Participant observation was utilized at community garden sites and at community garden events, such as Community Garden Council and Urban Agriculture Coalition meetings. Participant observation occurred before interviews in order to help in the selection of research sites and interviewees. I visited community garden sites between November 2018 and February 2019. The sites that I visited were $7^{\text {th }}$ Street, Emerson, Hope Community Farm, William F. Miles, Russell, Parkland, Garden of Goodness, the University of Louisville Garden Commons, and the Urban and Public Affairs Horticulture Zone. Participant observation allowed me to witness modes of collaboration and resource exchange within and/or between community gardens. Participants included 
people in charge of the community gardens and the gardeners themselves. Notes were taken using a notebook and transcribed immediately after the participant observation occurred. Observations made at multiple community garden sites, which are managed by two different types of organizations, enabled me to compare how resource sharing and collaboration manifest; these data serve as part of the basis for the analysis presented in Chapter Three.

In Phase Three, which occurred from February through April 2019, I analyzed the data collected in the first two phases to understand how collaboration and resource sharing manifests in Louisville community gardens. I hand coded my field notes and interviews to find emergent themes in the data (Bernard and Ryan 2010), using Descriptive Codes. Descriptive Coding uses one word to summarize the primary topic in a datum (Saldaña 2009). Coding enabled me to find commonalities and differences within my data (Saldaña 2009).

\section{Background/Literature Review}

\section{$\underline{\text { Urban Agriculture }}$}

Urban Agriculture (UA) is one example of how people are taking the growing of food into their own hands. UA is a part of alternative food networks (AFNs), where people are challenging the dominant narrative of industrial agriculture by reconnecting social connections between producers and consumers (McClintock 2014).

There is strong debate in the literature on whether urban agriculture is a radical response to industrial agriculture and the commodification of food or if it is reinforcing the neoliberal status quo (see McClintock 2014; Classens 2015). UA is thought to subvert 
neoliberalism by allowing people to access fresh, local food through non-commodified methods (McClintock 2014). Community gardens have flourished as a response to neoliberalism (Ghose and Pettygrove 2014). Yet UA can also benefit neoliberalism. McClintock (2010) explains that when people produce their own food, this means that wages can stay lower (197). By putting responsibility for food provisioning in the hands of the people, the state is freed from doing so (Classens 2015). McClintock (2014) argues that UA must be both neoliberal and radical, because it would not be "a viable social movement without elements of both, insofar as contradictory processes of capitalism both create opportunities for urban agriculture and impose obstacles to its expansion" (158). Understanding that a duality exists in UA means that research going forward can focus on the scale of UA processes, rather than trying to overcome contradictions.

The history of UA in the United States dates to the 1890s, when gardens emerged in schools and on vacant lots as a result of the socioeconomic environment (Draper and Freedman 2010: 459; Winne 2008: 55). Community gardens and urban agriculture became mainstream as a result of the World Wars and the Great Depression. Turning to urban agriculture in times of economic and social insecurity is a reoccurring trend, and as such it has been called many different names depending on how it was utilized. According to Cockrall-King (2012), a study by Charles Lathrop Pack said that there were over five million "Victory Gardens" in the United States after World War I. "Relief gardens" flourished during the Great Depression (Cockrall-King 2012:35), and World War II resulted in "Victory Garden" programs promoted by the U.S. Department of Agriculture to help with food shortages (Cockrall-King 2012; Draper and Freedman 2010; Mok et al. 2014; Winne 2008). According to Draper and Freedman (2010), the 
2009 recession caused a 19 percent increase in "recession gardens" to reduce the cost of family food bills (460).

The value of UA can be seen at multiple scales. Zezza and Tasciotti (2010) state that, regarding urban food security at the household level, "urban agriculture can be a source of income, can provide direct access to a larger number of nutritionally rich foods, ... can increase the stability of household food consumption against ... temporary shortages, and can increase the time mothers spend caring for their children" (266). At a broader level, Zezza and Tasciotti found indications that urban agriculture does have an impact on food security, though they could only find one quantitative study that was published (2010: 266). According to Mok et al., some cities produce up to 100 percent of specific fruits and vegetables in urban areas (2014: 22).

Other benefits from UA include "reduced food transportation distance, carbon sequestration, potentially reduced urban heat island effect, improved physical and mental health, improved aesthetics, community building, employment opportunities, improved local land prices, shortened supply chains and, thus, reduced price differentials between producers and consumers, provision of habitat for wildlife, and waste recycling" (Mok et al. 2014:22). UA can also increase multi-ethnic and multi-generational exchange of agricultural and culinary knowledge (McClintock 2014).

UA comes in many forms. McClintock (2014) states that the main types include Residential, Allotment, Guerrilla, Collective, Institutional, Non-profit, and Commercial (151). Residential urban agriculture includes gardens that are in yards and on balconies and porches. They are managed at an individual or household level and are done primarily for household consumption. Allotment gardens are what most community 
gardens in the United States are - plots used by individuals in communal areas for growing vegetables and other plants. Individuals or groups of people use guerrilla UA to create edible landscapes in public spaces. Collective UA is agriculture in urban spaces where labor is done collectively by the community, and usually have a garden manager. Institutional UA can be seen in schools, hospitals, and prisons; they tend to have a more educational purpose and are maintained by staff and volunteers. Non-profit UA is run by non-profit organization staff and volunteers, and are primarily done for food justice, education, and food security. Commercial UA is for food production and is run by a manager or owner and relies on employee labor. Many examples of UA can fit into multiple categories, which demonstrates how UA works across multiple scales (McClintock 2014: 150).

Types of UA are only limited by human ingenuity, technological innovation, and affordability. Beyond backyard gardening, community gardening, and greenhouses, there are creative types such as rooftop gardens (Cockrall-King 2012; Mok et al. 2014; Taylor and Lovell 2012), aquaculture (Cockrall-King 2012; Horst, McClintock, and Hoey 2017), and vertical farms (Cockrall-King 2012; Mok et al. 2014). Other unique forms of UA include urban vineyards and permaculture, which is where gardeners attempt to mimic natural ecosystems through the food landscapes they create (Cockrall-King 2012). The most well-known type of urban agriculture is the community garden (Poulsen et al. 2014). 


\section{Community Gardens}

Community gardens are urban spaces managed by community members where they grow food or flowers either collectively or individually (Glover, Shinew, and Parry 2005; Guitart, Pickering, and Byrne 2012). The literature does not have a standardized definition of community garden (Guitart, Pickering, and Byrne 2012), which would be useful for both qualitative and quantitative research on community gardens going forward. In the United States, most community gardens are community spaces where individuals lease a plot of land for personal use. The United Kingdom calls these types of community gardens “allotment gardens” (Cockrall-King 2012); McClintock (2014) gives a similar definition. Also described by McClintock (2014) are collective gardens, which are managed by community members and maintained collectively. This is one example of where confusion can occur in the literature when discussing community gardens.

There are many reasons that people establish community gardens. They can be spaces for cultural connection, identity expression, social interactions, and community development (Ghose and Pettygrove 2014; Pearsall et al. 2016). They also offer economic opportunity and provide fresh vegetables and fruit in urban food deserts (Draper and Freedman 2010; Ghose and Pettygrove 2014; Pearsall et al. 2016). Community gardens provide green space that has the potential to reduce the urban heat island effect (Mok et al. 2014). Community gardens have been established in recent years to "respond to poverty, environmental degradation, and the lack of safe green spaces in deprived urban places" (Milbourne 2012:946). The American Community Gardening Association estimates that there are over 18,000 community gardens in the United States (Mok et al. 2014). 
The literature on community gardens is broad. Draper and Freedman performed an extensive literature review on community gardens and find that the literature on community gardens can be divided into several types: case studies, reviews, interventions, and cross-sectionals (2010:477). Their expansive review found that the methods used were $49 \%$ qualitative, $40 \%$ quantitative, and $11 \%$ mixed-method (Draper and Freedman 2010:477). They analyzed the themes of the papers and found that nearly $50 \%$ of the papers discussed health benefits. Other themes included food security, economic development, youth education, development, and employment, use and preservation of open space, crime prevention, neighborhood beautification, leisure and outdoor recreation, cultural preservation and expression, social interactions/cultivation of relationships, and community organizing, empowerment, and mobilization (Draper and Freedman 2010:480-485). They write: "The published results of the studies highlight five main purposes and/or concerns related to community gardening: (a) engaging youth, (b) health (e.g., dietary, mental, and physical) benefits, (c) gardener versus land holder conflicts, (d) social capital, and (e) participant motivations and perspectives" (Draper and Freedman 2010: 486). This literature review demonstrates what research has been done on community gardens from all over the world, and highlights that there are many routes research can follow in the future. Guitart, Pickering, and Byrne (2012) emphasize that the literature is generally focused on the United States and that future literature should look beyond the U.S. socio-political context.

One of the challenges that community gardens face is with land use. According to Guitart, Pickering, and Byrne (2012), most land that community gardens are on is owned by the government, and "the main challenge faced by community gardeners in the USA 
has been security of tenure" (369). In Milwaukee, Wisconsin, the Department of City Development offers seasonal community garden permits, lasting either six months or three years. This is further challenged by land value: if a plot of vacant land has a higher real estate development value, then community garden permits may be denied (Ghose and Pettygrove 2014). Sometimes there is a conundrum - community gardens often raise the property value of a neighborhood, so this can result in land being taken away from gardens to be developed. Property value can go up as much as 9.4 percent in the first five years of a community garden's establishment (Barron 2016). This has occurred in New York City and in Los Angeles, "where up to 400 community gardens have been closed for redevelopment” (Guitart, Pickering, and Byrne 2012:369).

One such garden was South Central Farms in L.A. This community garden was created in 1994 by the LA Regional Food Bank in the hopes of furthering food security after the riots of 1992. "The gardens," as it was known, was set up with a "revocable permit" on vacant city property. The neighborhood has a large South and Central American population, many of whom had agricultural knowledge. Cockrall-King (2012) states that along with producing food, it also served as a "third-space," a place that Latino community members gathered to discuss news and hold celebrations (147). The gardeners cultivate between 100 and 150 plant species with practices like companion planting, including heirloom vegetables, fruits, and herbs that were important to the community. Property values rose because of how successful the gardens were. In consequence, the former land owner, Ralph Horowitz, wanted the parcel back. "Neither the decision to sell the land nor the sale price or terms of the sale agreement were publicly released until after the deal was done. Unbeknownst to the farmers, the site was 
quietly resold to Horowitz in a murky agreement" (Cockrall-King 2012:149). Gardeners became politically organized in an effort to fight back, which ultimately "ended with SWAT teams in riot gear arresting protesters and farmers, as well as bulldozers razing stands of corn, guava, and avocado trees" (Cockrall-King 2012:149-150) in 2006. The story of South Central Farms became well known when filmmaker Scott Hamilton Kennedy documented it in The Garden, an Oscar-nominated documentary. The land is once again abandoned, with the grooves left by the bulldozers viewable from Google Earth. It is under surveillance to prevent the return of any farmers (Cockrall-King 2012). This example of conflict over land demonstrates how cities frequently value commercial use over community use.

A study performed by Drake and Lawson (2014) looked at community gardens around the United States and Canada. They examined challenges that community gardens face, especially with operations and management. The four key issues they found were "the impact of organizational size on overall results, the role of networking, benefits from the perspective of organizations, and challenges faced by organizations" (Drake and Lawson 2014:245). They categorized community garden organizations based on size small organizations serve one garden, medium organizations serve two to three gardens, large organizations serve 4-30 gardens, and very large organizations serve over 30 gardens. The larger the organization size, the more likely they were to get local governmental support. Organizations reported that the primary reason for community garden losses was declining participation rather than land used. While every community garden will have local challenges that influence their use, overall, they share a common set of challenges: funding, participation, land, and materials. Drake and Lawson state, 
"Networking practices are common across the board, and this survey suggests an ontological shift in thinking of community gardens not as isolated, individual sites but as networked among many other local relationships" (2014:252). Research analyzing the ways that community gardens collaborate and exchange resources, especially gardens with long-term success, may help the long-term success of community gardens in development. Understanding how community gardens are situated within the community at large, and how this influences collaboration and research exchange, can help contextualize each community garden and how it exists in both time and space.

Network formation in urban community gardens is examined by Ghose and Pettygrove (2014) in order to gain a better understanding of the complexity of their formation. The authors conducted 21 semi-structured interviews with actors in the Harambee neighborhood of Milwaukee, interviewing residents, community garden organizers, nonprofit organization representatives, and city government agencies. They also did participant observation at four of the community gardens. Ghose and Pettygrove focused on how neoliberalism influences the formation of community gardens. Urban community gardens have relationships and boundaries among actors across multiple scales, so "it is important to analyze the spatiality of scales, and understand how horizontal networks of relations between actors and organizations interact with issues of scale" (Ghose and Pettygrove 2014:95). The authors argue that power dynamics are an important thing to look at when studying networks, especially with economic status. This will vary on a case-by-case basis, and in Harambee, many of the residents are marginalized and economically disadvantaged. This presents barriers for community garden development. However, "groups have managed to surmount or mitigate these 
challenges, primarily through territorially-scaled networks constructed among citizens, nonprofit organizations, City of Milwaukee agencies, and other actors" (Ghose and Pettygrove 2014:96). Ghose and Pettygrove discuss strong ties (transfer of resources) and weak ties (how actors gain the knowledge and information to enter into networks of strong ties). The authors argue that Harambee residents use networks "to establish community gardens" (Ghose and Pettygrove 2014:102). It is useful to examine how collaboration and resource sharing are used in the establishment and management of community gardens because this can demonstrate how actors overcome obstacles through social connections.

Every community garden is different, even when managed by the same organization. Each one is "rooted in its own unique, complex set of historical, cultural, and structural conditions" (Glover, Shinew, and Parry 2005:80). As noted above, community gardens have multiple uses, but one of the most common discussed in the literature is for low-income gardeners to grow fresh produce in areas that are food deserts (Cockrall-King 2012; Ghose and Pettygrove 2014; Glover, Shinew, and Parry 2005; Hanna and Oh 2000; Poulsen et al. 2014). Further research into how UA impacts food insecurity would be beneficial because the literature on community gardens in the United States tends to focus on the potential benefits of community gardens regarding food insecurity rather than actual results (Zezza and Tasciotti 2010). The work that has been done on food insecurity in the United States contrasts with international work on solutions to food insecurity from UA, such as work done in Cuba (cf: Altieri et al. 1999; Cockrall-King 2012; Gonzalez, 2003; Messina 1999). When approaching research on 
community gardens, understanding the unique, complex history and the actors involved are critical.

\section{$\underline{\text { Urban Political Ecology }}$}

Understanding the connections between social, economic, political, and environmental factors is the aim of Political Ecology (Greenberg and Park 1994; Johnston 2003). Political Ecology particularly examines the power dynamics of these connections, utilizing a variety of linked theoretical approaches. Understanding power dynamics is often critical to understanding the structural context of a specific situation, such as why local environments are being degraded, and by whom (Bryant 1998). Likewise, it is important to understand the local environment and its resources in order to understand the politics surrounding it (Sheridan 1995). For this reason, political ecology is an ideal framework to study sustainability issues. Topics such as water (Johnston 2003; Smith 2001), community gardening (Classens 2015; Milbourne 2012), resource management (Hohenthal, Räsänen, and Minoia 2018), and the urban environment (Cornea, Véron, and Zimmer 2015; Gabriel 2014; Milbourne 2012; Swyngedouw and Heynen 2003) are merely a small portion of the subjects studied in the extensive body of literature on political ecology.

Urban Political Ecology (UPE) is a framework that is "a geographic approach geared toward understanding the ways in which political, economic, and ecological processes work together to transform cities and the lives of the people who live in them" (Heynen 2017). UPE examines how urban and natural environments are inseparable. Urban and natural environments are frequently viewed as binary in both the literature and 
Western mindsets (see Cronan 1995; Heynen, Kaika, and Swyngedouw 2006; Marris 2011). This way of thinking views the city as the antithesis of nature (Heynen, Kaika, and Swyngedouw 2006). An example of this disconnect is the establishment of national parks in the United States; with one exception, U.S. national parks do not allow permanent human residents or resource use to preserve the natural environment. "The cult of pristine wilderness is a cultural construction, and a relatively new one. It was born, like so many new creeds, in America" (Marris 2011:15). But Jacobs (1992:443) argues that urban environments "are as natural as colonies of prairie dogs or the beds of oysters" (quoted in Heynen, Kaika, and Swyngedouw 2006:4). Classens (2015) argues that the separation of 'nature' and 'society' by scholars studying urban gardens results in them overlooking potential benefits to socio-political goals.

Just as humans have impacted most of nature through processes like carbon emissions and pollution, nature impacts how we create cities. Urban spaces are comprised of natural resources built through historical and sociocultural processes (Heynen, Kaika, and Swyngedouw 2006). UPE views urban areas as a process of socioecological change embedded in networks from local to global levels (Heynen, Kaika, and Swyngedouw 2006; Swyngedouw and Heynen 2003). It is particularly important to pay attention to political processes (Heynen, Kaika, and Swyngedouw 2006).

Cornea, Véron, and Zimmer (2017) state that one of the primary goals of UPE has been to understand how politics, economics, and power have influenced the unequal access of resources and services available in urban spaces. They argue that this research needs to be expanded to include micropolitics and everyday urban planning. Governance, and how it is experienced in everyday life, are thus important issues that need to be 
studied under the UPE framework. Agyeman and McEntee (2014) argue that UPE "situates socioecological processes, relationships, and metabolisms, which create unjust outcomes in space."

Capitalism and its uneven distribution of wealth and power has been a central focus of UPE, though scholarship has begun to move beyond this focus; many scholars are now looking at urban planning, self-governance, and micropolitics to understand the power dynamics between people, the economy, and the environment (Gabriel 2014). Cornea, Véron, and Zimmer posit that everyday governance actors are more important in understanding the unequal access to resources and services than structural power and elites (2017). They suggest that this approach differs from the Marxist, political economy-focused approach to understanding governance through UPE because governance should be approached from understanding the involved actors, which are specific to each situation. Rather than assuming that power dynamics in the urban setting are the result of a type of norm, we must look at each situation as context-specific.

Scale can be an important part of UPE. According to Swyngedouw and Heynen (2003), "cities are dense networks of interwoven sociospatial processes that are simultaneously local and global, human and physical, cultural and organic. The myriad transformations and metabolisms that support and maintain urban life — such as, for example, water, food, computers, or movies - always combine physical and social processes as infinitely interconnected" (899). Scale is often conceptualized as hierarchical in political ecology, but scholars also look at how scale can be horizontal, also referred to as networked (Zimmerer and Bassett 2003:4). Indeed, as noted above, this work connects directly to UA literature: Ghose and Pettygrove (2014) examine how 
horizontal networks between Harambee community garden actors interact across scales. Geographical scale is central to political ecology analysis (Neumann 2009; Zimmerer and Bassett 2003). Scale is "socially constructed, historically contingent, and politically contested" (Neumann 2009:399).

UPE can be used to study many aspects of urban life. Agyeman and McEntee (2014) argue that food justice (FJ) is one field of study that could be improved through UPE as a framework. The purpose of FJ is to identify and addresses unequal access to food. To fully understand FJ, you need to understand how environmental change, socioeconomic impact, and the political history of the study area. "After all, food is as politically entrenched, networked, historically bound, and tied to nature as other resources necessary for human survival" (Agyeman and McEntee 2014:216).

Similar to how Agyeman and McEntee (2014) examine FJ through UPE, urban community gardens are spaces that would benefit from research through the lens of UPE (Byrne et al. 2017). According to Milbourne (2012), urban community gardens are ideal places to study everyday socio-ecological injustices. Classens (2015) argues that we need to understand why urban gardens are created, and by whom. Funding can be unreliable for gardens, and "these ebbs and flows of funding have in some cases shaped by the urban agriculture landscape by defining where and what kinds of gardens have taken root and for whom" (McClintock 2014:164). Understanding how the gardens exist within the context of the urban neighborhood is critical in helping to ensure their longevity, in addition to creating new community gardens.

This thesis draws from several veins of scholarly work within UPE. I am drawing from Cornea, Véron, and Zimmer (2017) in my data analysis to look at how political- 
economic relations and unequal access to resources influence Louisville community gardens. I also connect micropolitics, everyday urban planning, and self-governance to community gardens (Cornea, Véron, and Zimmer 2017; Gabriel 2014). I further draw from Neumann (2009), Swyngedouw and Heynen (2003), and Zimmerer and Bassett (2003) when looking at the political ecology of scale. I bring these topics into conversation as I explore how collaboration and resource sharing manifest with Louisville community garden actors, examining the ways in which unequal access to resources and everyday decisions interact across multiple scales.

In Chapter Two, I give an overview of Louisville, Kentucky. I lay out the basic information about Louisville community gardens that I collected from interviews and participant observation, describe the actors involved with gardens, and discuss the relationships that exist across multiple scales. In Chapter Three, I provide the data that I collected on collaboration and resource sharing in Louisville community gardens. I then draw from this literature to analyze the data collected and determine how collaboration and resource sharing manifest across multiple scales at Louisville community gardens. 


\section{CHAPTER II}

In this chapter, I provide background on Louisville and its community gardens, including descriptions of the actors involved, such as organizations and funders. I present data that I collected through interviews and participant observation that will be the basis for my analysis in Chapter 3, where I discuss patterns of collaboration and resource sharing among the community gardens.

\section{Louisville, Kentucky}

The city of Louisville, Kentucky is located on the Ohio River, directly south from the state of Indiana. The city was founded by George Rogers Clark in 1778. Its location near the Falls of the Ohio meant that Louisville became a commercial city, quickly making it the largest city in Kentucky (“Louisville, KY History,” n.d.).

As of 2017, the population estimate was 621,349 , with the population being 70.5 percent white, 23.2 percent black, 5.2 percent Hispanic or Latino, 2.5 percent Asian, 0.1 percent American Indian or Alaska Native, 0.1 percent Native Hawaiian and other Pacific Islander, and 2.9 percent two or more races (U.S. Census Bureau). According to this census, 16.7 percent of people in Louisville are living in poverty.

Louisville is a racially segregated city. This is a result of multiple structural processes that are social, political, and economic. One such process is that of redlining, 
which "refers to the practice of denying loans in certain neighborhoods because of socioeconomic characteristics rather than physical, design, or structural characteristics"(“Redlining Louisville," n.d.). Redlining had a major impact on racial segregation in Louisville and is partially responsible for the economic disparity between the western part of Louisville and the eastern part of Louisville. In 1937, the Home Owners Loan Corporation (HOLC) developed redlining maps for Louisville, where neighborhoods were given a grade (A through D, or First through Fourth grades). Low income neighborhoods were marked C or D (Third or Fourth), which kept investors from developing in these areas and kept homeowners from being able to get a mortgage. According to Poe, "The First grade areas were described as new, homogenous and 'in demand as residential locations in good times and bad.' Homogenous meant 'American businessman and professional men.' Neighborhoods with Black or Jewish populations, or even those with the 'threat of infiltration' by such populations, were not considered 'best' or "American." ("Redlining Louisville," n.d.). One of the criteria for grading a neighborhood was, "restrictions set up to protect the neighborhoods" (Louisville Survey 1937). According to Poe, this referred to neighborhoods with deed restrictions prohibiting African Americans from owning property ("Redlining Louisville," n.d.; also see Lawrence 2005). Suburban sprawl furthered segregation in Louisville when citizens from higher socio-economic brackets, primarily white, moved out of the city and into the suburbs (Lawrence 2005; “Redlining Louisville,” n.d.).

Understanding the history of Louisville is critical to understanding the social, political, economic, and environmental processes that exist today. Knowing about the racial segregation and economic disparity in Louisville, and where these impacts still 
exist today, helps us understand the neighborhoods that community gardens are located, and how this might impact access to funding and resources.

\section{Food Insecurity}

Food insecurity is when people do not have access to enough food because of a lack of money and other resources (Nord, Andrews, and Carlson 2005). Community gardens are frequently discussed as a solution to food insecurity in the literature (Draper and Freedman 2010; Ghose and Pettygrove 2014; Mok et al. 2013; Pearsall et al. 2016). Many Louisville neighborhoods are highly food insecure. Today, the neighborhoods that make up the areas of western and southern Louisville are generally occupied by individuals with incomes in the range of $\$ 0$ to $\$ 46,733$ ("Redlining Louisville," n.d.). According to the Courier Journal, more than 120,000 people in Louisville are living with food insecurity (Loosemore 2019b). The U.S. Department of Agriculture declared certain parts of Louisville as food deserts in 2015 (Loosemore 2019b). This means that approximately 44,000 residents cannot access or afford healthy food (Loosemore 2019a). Many West End neighborhoods no longer have grocery stores, only dollar stores (Loosemore 2019b). Louisville Mayor Greg Fischer explained that it's difficult to address the problem of food deserts because large corporations are the ones closing supermarkets (Loosemore 2019a). The Mayor is prioritizing the issue of food insecurity. "In its 20182019 budget, the city awarded nearly $\$ 400,000$ to six food-related organizations and another $\$ 1.1$ million to 15 ministries that provide emergency assistance, including food," (Loosemore 2019b). 
There are already efforts to combat food insecurity in Louisville through fresh, local produce. One organization, called New Roots, has a mission "to ignite community power for fresh food access. Our vision is that affordable, fresh organic food is available year-round in all Kentuckiana communities. We believe that just like air \& water, everyone has a right to fresh food. In a nutshell, we are uniting communities to spread food justice" ("Mission, Vision, and Values," 2019). Their primary focus is their Fresh Stop Markets, where people in food insecure areas can purchase fresh, local food. They will have six of these markets in Metro Louisville for the 2019 growing season ("Mission, Vision, and Values," 2019). Another program that exists to reduce food insecurity is the Kentucky Double Dollars (KDD) program. The KDD program "is a partnership between Community Farm Alliance (CFA) and Bluegrass Farm to Table (BGFtT) and is intended to: a) Increase access to local food, especially fresh and healthy, to low income populations, b) Increase sales and income to Kentucky farmers, and c) Leverage federal food and nutrition program funds, specifically the WIC Farmers' Market Nutrition Program (WIC FMNP), the Senior Farmers' Market Nutrition Program (SFMNP), and the Supplemental Nutrition Assistance Program (SNAP). Multiple partners including federal, state, and private funding support the Kentucky Double Dollars program" ("Who We Are," n.d.). This program allows people using benefits such as SNAP to purchase twice as much locally grown produce at farmers markets than the normal value. Innovative programs such as KDD and Fresh Stop Markets support local farmers and help fight food insecurity, but they are currently not enough to end food deserts. 
Access to fresh, local food is a primary focus for organizations trying to end food insecurity and food deserts. With community gardens available in neighborhoods with food insecurity, they are one potential avenue to fighting food insecurity in Louisville.

\section{Louisville Community Gardens}

Research into Louisville's community gardens is relatively new, despite their decades of existence. Thesis research on Louisville and nearby community gardens has been completed at the University of Louisville in previous years (cf: Dietche 2018; Montgomery 2016; Short 2016). These theses focused on other aspects of community gardens, including state-reinforced self-governance, communality, and food justice, respectively.

Louisville community gardens are nested within multiple scales. At the federal level, funding and grants are sometimes available to community gardens and organizations, such as for refugee programs. The two land-grant universities in Kentucky, the University of Kentucky and Kentucky State University, partner with the Jefferson County Cooperative Extension to provide educational programs to Kentuckians ("About Us," n.d.). At the local level, zoning is important for the establishment of community gardens. Some of the funding and resources for Louisville community garden are provided by the city of Louisville.

At the start of my research, there was no up-to-date, comprehensive list of existing community gardens and community farms. The Food in Neighborhoods Coalition (FIN) website has a map of community gardens that was last updated in 2017 ("Urban Agriculture Map," n.d.). Some of the gardens are no longer in existence, 
including Shippingport Community Garden and Billy Goat Hill Garden, which closed in late 2018. The map shows that most of the gardens are in neighborhoods in western parts of Louisville.

Table 1: Louisville Community Gardens

\begin{tabular}{|c|c|c|}
\hline $\begin{array}{l}\text { Community } \\
\text { Garden }\end{array}$ & Organization & Neighborhood \\
\hline $7^{\text {th }}$ Street & $\begin{array}{l}\text { Jefferson County } \\
\text { Extension Office }\end{array}$ & Shively \\
\hline $\begin{array}{l}\text { Americana } \\
\text { Community Center }\end{array}$ & $\begin{array}{l}\text { Americana } \\
\text { Community Center, } \\
\text { Inc. }\end{array}$ & Southside \\
\hline Blackacre & $\begin{array}{l}\text { Blackacre } \\
\text { Conservancy }\end{array}$ & Jeffersontown \\
\hline Blue Lick & $\begin{array}{l}\text { Jefferson County } \\
\text { Extension Office }\end{array}$ & Blue Lick \\
\hline $\begin{array}{l}\text { Buechel Park } \\
\text { Baptist Church }\end{array}$ & $\begin{array}{l}\text { Buechel Park } \\
\text { Baptist Church }\end{array}$ & Buechel \\
\hline Emerson & $\begin{array}{l}\text { Jefferson County } \\
\text { Extension Office }\end{array}$ & Schnitzelburg \\
\hline Farnsley-Moremen & $\begin{array}{l}\text { Jefferson County } \\
\text { Extension Office }\end{array}$ & Valley Station \\
\hline Francis Center & $\begin{array}{l}\text { St. John Paul II } \\
\text { Parish }\end{array}$ & Klondike \\
\hline $\begin{array}{l}\text { Garden of } \\
\text { Goodness }\end{array}$ & Privately owned & Old Louisville \\
\hline $\begin{array}{l}\text { Hope Community } \\
\text { Farm }\end{array}$ & $\begin{array}{l}\text { Gate of Hope } \\
\text { Ministries }\end{array}$ & Beechmont \\
\hline Limerick & $\begin{array}{l}\text { Jefferson County } \\
\text { Extension Office }\end{array}$ & Limerick \\
\hline Millers Lane & $\begin{array}{l}\text { Jefferson County } \\
\text { Extension Office }\end{array}$ & Rubbertown area \\
\hline $\begin{array}{l}\text { New Hope } \\
\text { International } \\
\text { Community Farm }\end{array}$ & $\begin{array}{l}\text { Passionist Earth \& } \\
\text { Spirit Center }\end{array}$ & Deer Park \\
\hline $\begin{array}{l}\text { Okolona Christian } \\
\text { Church }\end{array}$ & $\begin{array}{l}\text { Okolona Christian } \\
\text { Church }\end{array}$ & Okolona \\
\hline Old Louisville & & Old Louisville \\
\hline Parkland & $\begin{array}{l}\text { Jefferson County } \\
\text { Extension Office }\end{array}$ & Parkland \\
\hline
\end{tabular}




\begin{tabular}{|c|c|c|}
\hline $\begin{array}{l}\text { The People's } \\
\text { Garden }\end{array}$ & Louisville Grows & Shawnee \\
\hline Portland Garden & Louisville Grows & Portland \\
\hline Russell & $\begin{array}{l}\text { Jefferson County } \\
\text { Extension Office }\end{array}$ & Russell \\
\hline $\begin{array}{l}\text { Shawnee } \\
\text { Community Garden } \\
\text { of Principles }\end{array}$ & $\begin{array}{l}\text { Shawnee Christian } \\
\text { Healthcare Center }\end{array}$ & Shawnee \\
\hline Shelby Park & $\begin{array}{l}\text { Shelby Park } \\
\text { Neighborhood } \\
\text { Association }\end{array}$ & Shelby Park \\
\hline Southside & $\begin{array}{l}\text { Jefferson County } \\
\text { Extension Office }\end{array}$ & Southside \\
\hline $\begin{array}{l}\text { UofL Garden } \\
\text { Commons }\end{array}$ & $\begin{array}{l}\text { University of } \\
\text { Louisville }\end{array}$ & $\begin{array}{l}\text { University of } \\
\text { Louisville (Belknap } \\
\text { Campus) }\end{array}$ \\
\hline $\begin{array}{l}\text { Urban \& Public } \\
\text { Affairs Horticulture } \\
\text { Zone }\end{array}$ & $\begin{array}{l}\text { University of } \\
\text { Louisville }\end{array}$ & $\begin{array}{l}\text { University of } \\
\text { Louisville (Belknap } \\
\text { Campus) }\end{array}$ \\
\hline William F. Miles & $\begin{array}{l}\text { Jefferson County } \\
\text { Extension Office }\end{array}$ & Middletown \\
\hline
\end{tabular}

There are 25 active community gardens as of April 2019, all managed or overseen by different organizations and neighborhoods. The Jefferson County Cooperative Extension Office manages ten community gardens, which is more than any other organization in Louisville. I give an overview of the main actors involved with Louisville community gardens in the remainder of the chapter.

\section{$\underline{\text { Jefferson County Extension Office }}$}

The Jefferson County Extension Office (JCEO) is one of the University of Kentucky and Kentucky State University’s extension offices (“Jefferson County Cooperative Extension: About Us"). They provide educational services to Kentucky residents; their goals are to improve quality of life and to help build better communities. 
Bethany Pratt is a horticulture agent for the JCEO, whom I interviewed on December $5^{\text {th }}, 2018$. She oversees all ten community gardens and provides education and support for public or private garden spaces in Louisville. She hosts classes from April to October at various JCEO community gardens; any garden user is welcome to attend. Garden users can request to meet with Bethany at the gardens and can contact her with questions. In the interview with Bethany she said, "Most of my job is people management. It's very little to do with plants."

Gardeners were concerned about where their money was going when they leased plots, so Bethany established the Community Garden Council. I asked Bethany about the purpose of the council, and she explained that gardeners ask for resources, including picnic tables, shelters, plants, seeds, manure, and compost. The council is a way to be transparent about the budget. This council gives gardeners control and oversight over the program. They meet on a quarterly basis, or more frequently if the gardeners request it. I attended the winter quarterly meeting in January 2019. Five gardeners and garden managers from Emerson Community Garden, $7^{\text {th }}$ Street Community Garden, and Parkland Community Garden attended this meeting. The main point of the meeting was to discuss the budget but talk also included changing the date of the annual Harvest Party. The Harvest Party is an annual event that gardeners from all ten gardens are invited to attend, which gives gardeners from around the city an opportunity to meet and connect.

The following week I attended a community garden manager meeting at the JCEO. This meeting highlighted the responsibilities that community garden managers must undertake when volunteering or being hired on, and how challenges within community gardens must be navigated with the gardeners and garden managers. Garden 
managers from William F. Miles, Limerick, Parkland, $7^{\text {th }}$ Street, Emerson, and Blue Lick were in attendance. Garden managers, both paid and unpaid, start their position on March $15^{\text {th }}, 2019$ to prepare for the 2019 growing season. Bethany and the garden managers reviewed policies in place to keep the gardens safe and presentable. The policy for "weed warning” flags was explained - if a garden looks unkempt and is overgrowing, garden managers place a yellow warning flag with the date, plot number, and JCEO phone number. If they do not maintain it within two weeks, garden managers place red flags that mean the garden has been forfeited. If a garden is forfeited, managers can call people on the garden waitlist to see if they want to take over the plot. In my interview with Bethany, she explained that she introduced this communication system for transparency. Prior to her being hired, letters of warning were mailed to plot renters and no signal showed that something was being done about overgrown plots to other gardeners. Visual communication allows other gardeners to see that something is being done about overgrown plots and ensures that all gardeners receive the message clearly. "That's always a challenge with a lot of cultures in one space, there's lots of room for misunderstanding and confusion because our systems are different and it's no good to send somebody a letter if they don't read English," Bethany explained. Another major role for garden managers that was discussed is conflict resolution. The previous year there were instances of people threatening each other because of plants growing over into the other person's plot, as well as conflict because of the ethnicity of another gardener. They implemented a new policy with a bullying and harassment clause; if caught harassing another gardener, they receive a yellow harassment flag. If it happens again, their garden is forfeited. 
The Community Garden Council's February meeting was at the Golden Corral on the evening of the 19th. This meeting provided useful information about who uses the gardens and the future of Russell community garden. The meeting also provided more insight into how gardeners can influence how the community gardens are run. Three gardeners from $7^{\text {th }}$ Street - Carol, her husband Don, and Sarge - and Richard from Emerson were in attendance. Bethany and the $7^{\text {th }}$ Street gardeners discussed the planned in-person sign-ups at $7^{\text {th }}$ Street the following week. Many of the gardeners at $7^{\text {th }}$ Street do not have permanent housing, which means that the JCEO cannot mail the plot sign-up form to a specific address. This makes in-person sign-ups necessary for inclusivity. Russell Community Garden had no garden manager for 2018 and no new sign-ups, but Bethany said that the neighborhood association is organizing to possibly take on the community garden. The discussion then moved on to the topic of garden managers. Bethany asked the gardeners whether certain gardens should have paid managers. Bethany and the gardeners debated the criteria for whether a garden should have a paid manager. The gardeners agreed that when the current paid managers step down, they would consider ending paid manager positions.

The gardens are on public land, including land owned by Louisville MSD, Metro Parks, and Urban Renewal. If Louisville Metro decides to use the land these gardens are on for other purposes, the gardens will cease to exist. Individuals who lease plots through the JCEO must sign an agreement not to build any permanent structures on their plots and are discouraged from planting any trees or woody bushes because they would be responsible for removing them if the land was developed. 
I selected two community gardens managed by the JCEO as case study sites. The first was Emerson Community Garden, located in Schnitzelburg. The median household income for Schnitzelburg in 2015 was $\$ 45,079$, slightly less than the median income for Jefferson County, which was $\$ 48,695$, and ten percent of households receive SNAP benefits ("Louisville Neighborhood Profiles," 2017). The garden, which is over twenty years old, is located in Emerson Park. It is one of the gardens that Operation Brightside, an organization that "works to unite people in clean and green activities to beautify the city and foster community pride" (“About Brightside," n.d.), started for a program for seniors to grow their own vegetables. It has 78 plots and as of winter 2019, has a waitlist of 35 people.

I visited the garden in December and placed my contact information in the information kiosk, and a few weeks later I received a text from a gardener named Dave. We met at a coffeeshop in Germantown in January for an interview. Dave is a white gardener in his early sixties. He has been gardening since he was a child. Dave described Emerson as a garden used and visited by neighbors and friends. Emerson is a very communal garden. They host an annual harvest party, do coffee and donuts, and other events. Some gardeners tend to their plots more often than others. He visits the garden on a regular basis, usually every other day, sometimes for plot maintenance and sometimes just to hang out. He enjoys the process of growing things; he buys his own seeds and starts them in February. Dave volunteers for the JCEO; Bethany asks him if he wants to help with a new task or project involving garden maintenance and he says yes. These tasks can include picking up trash, doing early season sign-ins, among others. Dave 
introduced me to the Emerson garden manager Richard at the January Community Garden Council meeting.

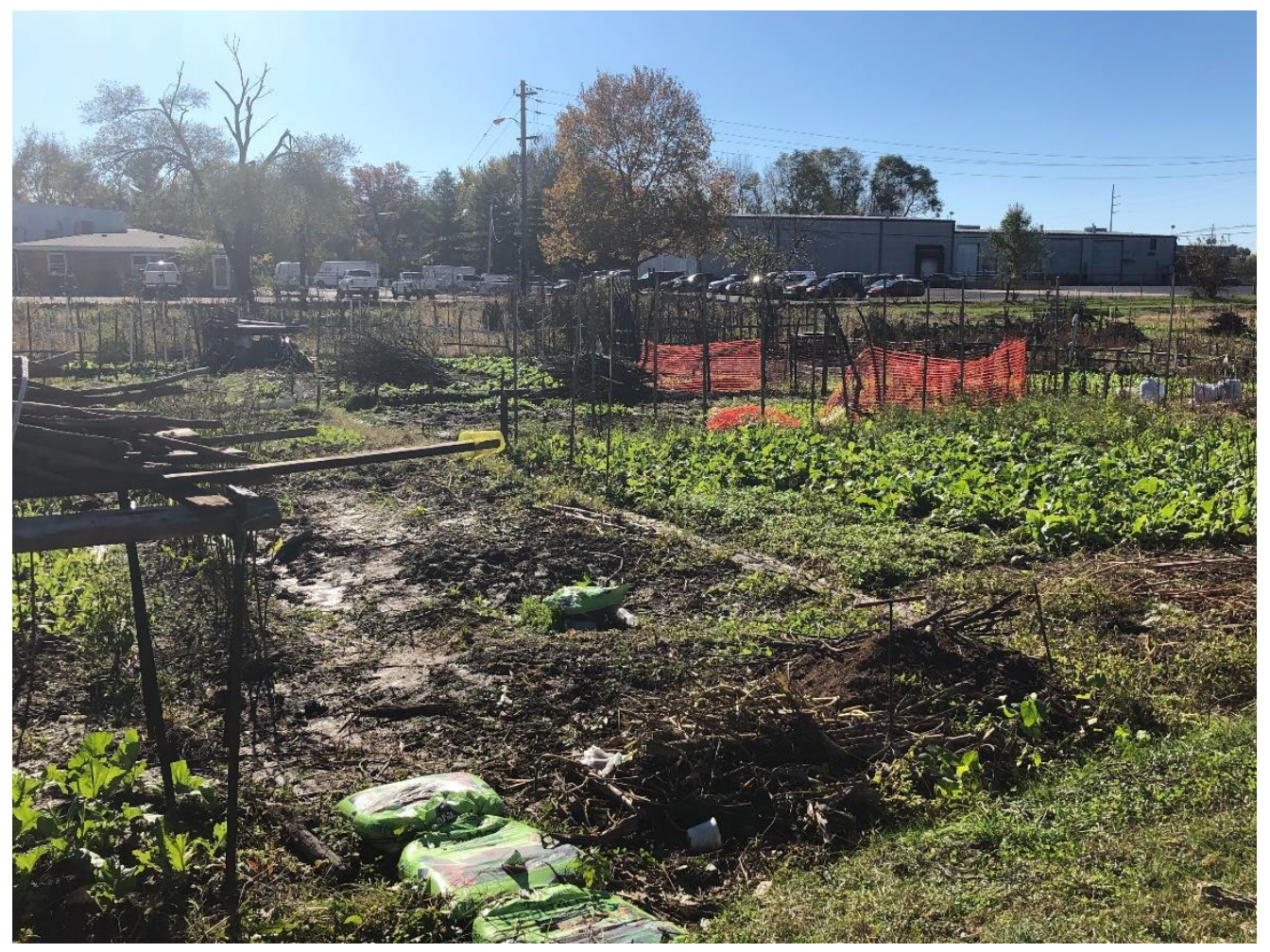

Figure 1: Plots at $7^{\text {th }}$ Street Community Garden. November 2018. Photo by Emily Goldstein. 


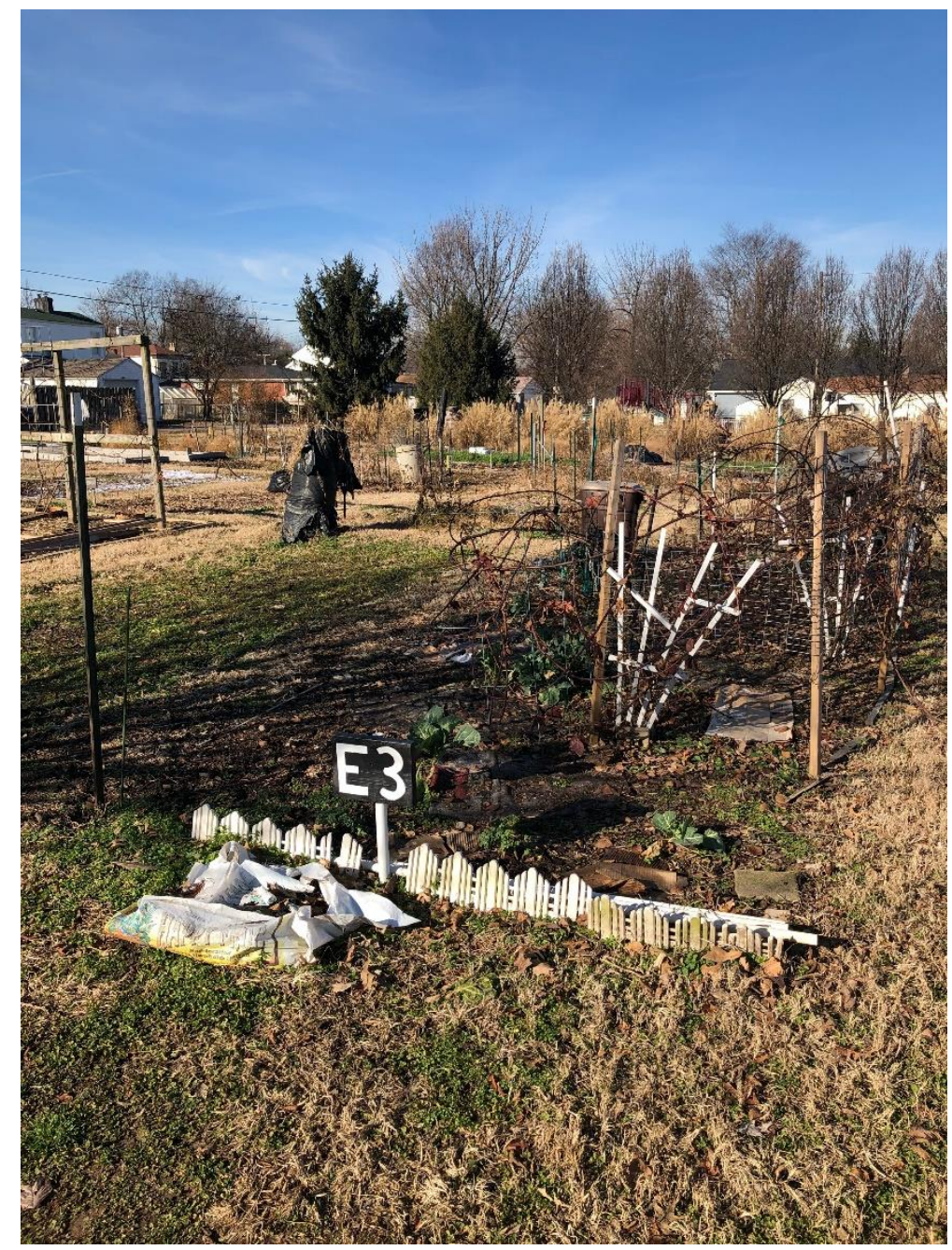

Figure 2: Plots at Emerson Community Garden. December 2018. Photo by Emily Goldstein.

I selected $7^{\text {th }}$ Street Community Garden as the second JCEO community garden case study site, which is located in the Shively neighborhood on $7^{\text {th }}$ Street Road. The annual income for Shively households was $\$ 33,490$ in 2015 , and 24 percent of households receive SNAP benefits. ("Louisville Neighborhood Profiles," 2017). Bethany recommended this garden to me because of its size and the diverse population that gardens there. The garden has 265 plots that are leased to over 100 gardeners. I met a gardener named Carol through the Community Garden Council, and she invited me to 
interview her in her home. I was surprised to find that her husband Don, who also leases plots at $7^{\text {th }}$ Street, wanted to be interviewed as well.

Both Carol and Don are white, middle class, and are 75 and 80 years old, respectively. They have been gardening for over 30 years. They have gardened at $7^{\text {th }}$ Street since it opened 20-30 years ago; it was another garden started by Operation Brightside for their senior gardening program. Carol and Don like to garden because they love having fresh vegetables like tomatoes. They also like to share information such as how-to demos and vegetables with other gardeners. They both love to meet new people at community gardens. Carol told me that she loves learning from different cultures; there are several Somali-American gardeners that lease plots. She noticed that they wrapped shirts around corn, and when she asked what they were doing, she learned that this was their way to protect the corn from squirrels. Somali-Americans plant unique species of plants such as caster beans, which help keep pests away from other crops. They shared pepper seeds with Carol and Don. When Somali-American gardeners plant corn, they perform a ritual of prayers. She also learned that Nepali-American gardeners were using corn stalks for mulch. She described how every autumn the Nepali-American gardeners have a ceremony when picking marigolds for rituals.

Both Carol and Don attend garden council meetings. During the growing season, Carol is at the garden in the morning and evening. Carol is the assistant manager at $7^{\text {th }}$ Street, and her role as assistant manager is to loan out communal tools, help gardeners when they ask for assistance, and help Bethany with classes.

Catholic charities send interpreters for meetings for the Nepali-American and Somali-American gardeners. I witnessed this when I volunteered to help with the in- 
person sign-up in February. The interpreters and the children of gardeners helped fill out the plot lease agreement forms. Despite the fact that it was pouring down rain and that we were standing on tarps quickly filling with mud, over a dozen gardeners came to pay their plot fees for the 2019 growing season.

\section{$\underline{\text { Hope Community Farm }}$}

Gate of Hope Ministries International manages a community garden and a Community Supported Agriculture (CSA) farm for Rwandan refugees, called Hope Community Farm. It is located in the Beechmont neighborhood in South Louisville, where the median income for households in 2015 was $\$ 40,796$ and 18 percent of households receive SNAP benefits ("Louisville Neighborhood Profiles," 2017). The Farm is on seven acres of property owned by Louisville Metro Housing Authority and is leased to the local urban agriculture organization Louisville Grows. Haileigh Arnold, the new farm manager, explained that the Farm hopes to eventually take over the lease from Louisville Grows. The property is shared by the Food Literacy Project (FLP), Louisville Grows, and South Points community garden; FLP uses a majority of the property. Haileigh is white and in her mid-twenties. When I interviewed her in November 2018, she explained, "The Farm first started by partnering with Louisville Grows because at the time, Gate of Hope didn't have the capacity to start a farm. They didn't have the knowledge or the manpower, and they didn't have the legal capabilities of owning a piece of land." For the first several years, the garden manager was a Louisville Grows staff member. This changed when Louisville Grows hired a new director; Louisville Grows then put more power into the hands of Gate of Hope. Gate of Hope is responsible for their 
own garden manager now, but the Farm is still dependent on resources provided by Louisville Grows.

Two-thirds of the land used by Hope Community Farm is for the refugee community garden; the rest is used by the community farm for CSAs. Garden users, referred to as "growers," can work for the CSA farm and/or lease a plot for \$20. There are 40 to 50 plots available to be leased by growers, but each plot may be used by more than one grower.

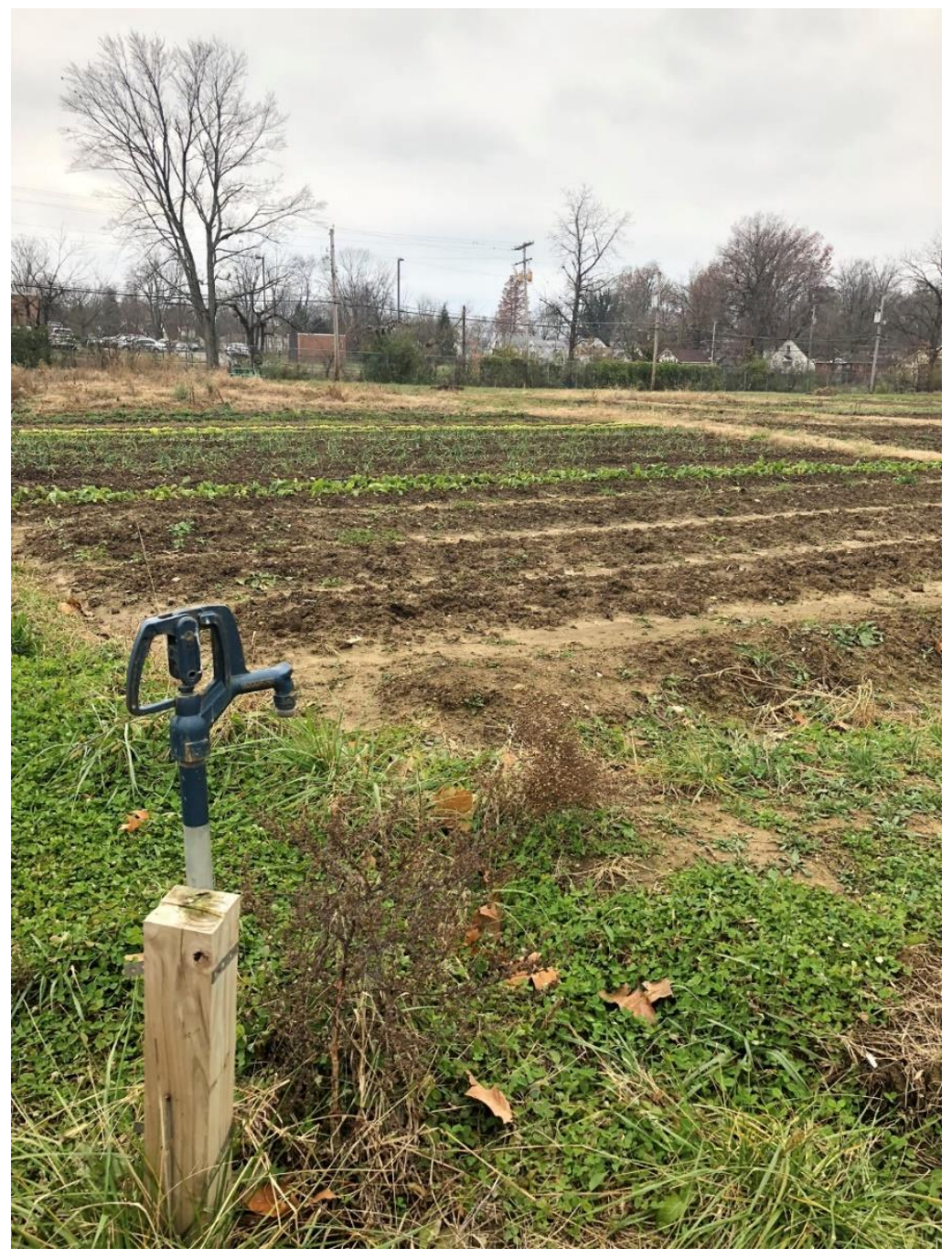

Figure 3: Hope Community Farm. December 2018. Photo by Emily Goldstein. 
The land that the Farm was built on was formerly an apartment complex called Iroquois Apartments. Haileigh informed me about the history of the land and how violence in the area made neighbors cautious. Hope Community Farm staff explained their mission to neighbors that approached them with their concerns, and neighbors were happy that the land was being used for something positive.

Soil quality is critical for growing healthy produce. The former land use caused the soil to be extremely compacted. The demolition of Iroquois Apartments filled the soil with rubble, rocks, and plastic. The Farm started producing vegetables on the land in 2014, but it has taken several years to make the CSA business profitable. It requires a lot of physical labor to prepare the soil to grow plants. When Haileigh gave me a tour of the property, she explained that the FLP has one farm manager to work the soil on their part of the property but have had poor crop results. The number of growers at Hope Community Farm and Louisville Grows volunteers that work the soil is what makes Hope Community Farm so successful at growing crops.

\section{Community Garden Supporters and Funders}

There are a multitude of organizations and companies that provide help for community gardens in Louisville. The urban agriculture organization Louisville Grows is one of the primary organizations that provides support for community gardens in Louisville. The organization was founded in 2009 and has changed drastically in that time frame. According to their website, Louisville Grows' mission is "to grow a just and sustainable community through urban agriculture, urban forestry, and environmental education” (“About,” 2019). 
Louisville Grows offers a non-financial annual community garden grant that provides recipients with resources such as materials, services, workshops, and volunteer help. I interviewed Simon Cozzens, Louisville Grows' Urban Agriculture Program Manager, in November 2018. He manages two programs for Louisville Grows, the Seeds and Starts sale and the community garden grant. The Seeds and Starts Sale serves as a fundraiser for the grant; volunteers start 30,000 plants in the greenhouse at the Peoples' Garden and then sell them. The 2019 season will be the third year that Louisville Grows has provided the grant. It is a year-long process that starts in October. Louisville Grows hosts information sessions about the grant; I attended one in November 2018. Louisville Grows provides a toolkit that is meant to give people an idea of what is involved with starting and running a community garden from a planning standpoint. Seven winners are chosen on average, though the 2019 season selected four gardens to receive the grant. When asked how they select winners, Simon explained, "They're chosen for a lot of reasons. They can be new gardens or expanding gardens that serve the mission of Louisville Grows in their own way. So sometimes that's supporting food production where there otherwise wouldn't be fresh food in a certain area or working with certain populations that are disadvantaged or at risk or in need of a community garden for whatever reason." For a community garden to win the grant, they must fulfill some part of their mission - particularly, they must have to do with food.

Another organization that assists Louisville community garden users is the Jefferson County Soil and Water Conservation District. I met with the organization's Urban Agriculture Conservationist, Lilias Pettit-Scott, in January 2019 for an interview. Her goal is to encourage local food production while protecting soil and water. She offers 
workshops and helps provide some resources to community gardens. When asked what resources are needed for community gardens, Lilias first said water. Other important resources she mentioned were land ownership and the community garden users running the garden themselves. She is a member of the Food in Neighborhood's (FIN) Urban Agriculture Coalition and believes that it could be a resource for community gardeners.

The Urban Agriculture Coalition was established in 2017 and is working "to create an equitable and resilient food system in Louisville by supporting and expanding home and community based food production and distribution, providing agricultural education and resources, and restoring the relationships between our gardens and their communities and ecosystems" ("Grow With Us," n.d.). They meet on a monthly basis. At the November 2018 meeting at the Table restaurant, ten people from various urban agriculture organizations around Louisville attended, including the JCEO, Jefferson County Soil and Water Conservation District, Louisville Grows, and Common Earth Gardens. This meeting demonstrated how people from multiple urban agriculture organizations can team up to perform gardening tasks. The discussion primarily focused on urban orchards around the city that needed pruning, including the Portland Orchard Project and other Louisville Grows community orchards. The goal with this program, nicknamed "The Orchard Brigade," is to aid community members in caring for the fruit trees, not to manage the community orchards for them. The February meeting met at the Common Earth Gardens building, with many of the same organizations in attendance. The meeting demonstrated that they can accomplish tasks by working together; the Orchard Brigade was a success, and they moved on to discuss future projects. The Urban 
Agriculture Coalition is a resource that brings people from urban agriculture organizations across Louisville together.

There are other types of organizations that provide resources for community garden users. Catholic Charities of Louisville, Inc. has a program called Common Earth Gardens, which improves the lives and empowers refugees through agriculture.

According to their website, Common Earth Gardens supports eleven community gardens that over 475 refugees utilize (“Community Gardens”, n.d.).

In an interview with Rachel Brunner, the program manager, in February 2019, she explained that her role is to provide support for refugees at four community gardens. She works with garden leaders and provides garden leader training. She also helps gardeners create a vision for that space and to take ownership of that space. Common Earth Gardens provides trainings once a month during the growing season. She said, " $99.9 \%$ of the people have been farmers most of their lives, and so giving power to that knowledge, working with them to answer questions they might have specific to growing in Kentucky, which might be a new climate.” The four gardens they support include the St. Ignatius garden, the $7^{\text {th }}$ Street community garden, the Southside community garden, and Peaceful Eden community garden. She also supports a community farm where everyone grows and harvests together, and an incubator farm where people learn farm business skills.

I asked Rachel how the two JCEO gardens that they support - Southside and $7^{\text {th }}$ Street - became a part of this program. She explained that these two gardens were the first gardens established with the Refugee Partnership Program, which is what the program used to be called. This was also the name of the federal grant that the program received beginning in 2007, which funds most of their work through the Office for Refugee 
Resettlement. Southside Community Garden is located on property owned by Antioch Church, so connections were made to allow refugees to use garden space. Refugees began using $7^{\text {th }}$ Street Community Garden in 2008 or 2009. Rachel explained, "Much of the support that happened between 2007 and 2017, when I started, looked like more hands-on management from the program side. It seems like there wasn't much conversation about how gardeners could identify their own problems and gather together to organize themselves. With my experience with community gardens over the past eight years, with a lot of US-born growers as well as refugee growers, I think that's a vital part of community organizing and community gardens, is to make sure that the people who are participating have ownership of that space and what goes on, and know that their opinion matters, and that there are community decision-making processes in place.” In Chapter Three, I draw from the literature in Chapter One to analyze the data I collected and discussed. Through this analysis I determine how collaboration and resource sharing manifest across multiple scales at Louisville community gardens. 


\section{CHAPTER III}

In this chapter, I first give an overview of data collected on collaboration and resource sharing among community gardens in Louisville, Kentucky. I then look at emergent themes in the data and in my analysis draw from the scholarly literature and theoretical framing presented in the first chapter. Through this analysis I determine how collaboration and resource sharing manifest across multiple scales at Louisville community gardens.

During my research, I interviewed three community garden users and five people involved with community garden organizations. These interviews included many of the major actors involved with Louisville community gardens, as there is a relatively tight community around urban agriculture in the Louisville area. Visiting garden sites allowed me to visualize where they are situated in surrounding neighborhoods, to see the garden sizes, to assess what resources were out and visible, and to get a sense of how they are used. Visiting gardens also allowed me to gain a perspective that might not have been mentioned in any interviews. Throughout this research, emergent themes began to appear in the data.

In the process of collecting and coding data, it became clear that in order to understand the types of collaboration and resource sharing that occur in Louisville community gardens, it was important to look at the shared challenges that the gardens face. Repetitions began to appear while coding interview transcripts and participant 
observation notes; these repetitions are emergent themes, and they include funding limitations, physical resources, transparency, inclusivity, community building, leadership, land ownership, and education. Two of the most common types of physical resources used in the gardens were compost and manure, and they were often obtained from the same sites. For example, manure from LMPD Mounted Patrol as a resource was mentioned by three different interviewees and at a meeting.

It also became clear over the course of my research that the amount of people and organizations that are involved with community gardens in Louisville is relatively small, because partnerships and collaboration exist between various groups. Lilias Pettit-Scott from the Jefferson County Soil and Water Conservation District provides resources to people involved with urban agriculture, and she directly work with JCEO community gardens. Rachel Brunner from Common Earth Gardens partners with Bethany Pratt from the JCEO to provide community garden resources for refugees in Louisville. Bethany Pratt is a resource for all community gardeners at JCEO gardens, as well as for anyone else in Louisville with questions about gardening. The JCEO offers soil testing for gardeners, which the Jefferson County Soil and Water Conservation District has soil vouchers to cover the cost of up to two soil tests per resident. Louisville Grows partners with and supports Hope Community Farm and have helped establish or support other community gardens with their annual community garden grant. They provide resources for urban gardens around Louisville. Multiple people recommended Bethany Pratt as an interviewee, indicating that she is an important actor for community gardens in Louisville. And finally, the Urban Agriculture Coalition demonstrated that there is a central group that helps to organize people involved with urban agriculture and 
community gardens in Louisville. Interactions observed between actors was largely positive during my research. This outcome might have been influenced by the fact that thesis data was collected over a relatively short period of time and because I am a newcomer to the UA community in Louisville. Louisville also has a tighter UA community compared to community garden actors in larger cities like New York City (cf: Smith and Kurtz 2003), which may shape interactions.

The Urban Political Ecology of community gardens in Louisville shows a complex web of connections that exists across multiple scales. The community gardens are deeply rooted in the history of Louisville, by who owns the land, and by where the garden is located. Despite the many differences between the various community gardens, they all share similar struggles. Collaboration and resource sharing allow actors involved with community gardens to exist with, if not overcome, these challenges.

\section{Data Analysis: Collaboration and Resource Sharing}

Community gardens often share similar issues in their establishment, running, and maintenance. These challenges usually result from situations at the local level, but community gardens tend to share these challenges at multiple scales. These challenges are funding, participation, land, and materials (Drake and Lawson 2014).

Every community garden faces unique problems based on local context (Glover, Shinew, and Parry 2005), but funding, participation, land, and materials are common challenges for all types of community gardens, no matter what type of organization runs the gardens. Like how Agyeman and McEntee (2014) approach food justice through a lens of UPE, community garden research would also benefit from this approach. Just like 
food, the community gardens that grow food are "as politically entrenched, networked, historically bound, and tied to nature as other resources necessary for human survival" (Agyeman and McEntee 2014:216).

In order to talk about collaboration and resource sharing at community gardens, the shared challenges that the gardens face must first be discussed. Below I compare the challenges that each case study site and other community gardens in Louisville face. I categorize the challenges into Funding, Resources, and Land Ownership. I also describe ways that gardeners use collaboration and resource sharing to overcome these challenges or, at the least, exist with them.

\section{Funding}

Of the multiple challenges Louisville community gardens face, I argue that funding is the most limiting. Funding can be reliable or not depending on the type of organization, but available financial resources are usually not sufficient enough for gardens to purchase all of the resources that they need.

The annual cost for all ten gardens managed by the JCEO is between $\$ 65,000$ to $\$ 75,000$ for basic upkeep and management. This includes lawn mowing, renting port-opotties, waterline maintenance, and tools and tool upkeep. Louisville Metro government provides $\$ 50,000$ to run the community garden properties, and another $\$ 10,000$ to $\$ 11,000$ is provided by plot fees. According to Bethany Pratt, the amount of $\$ 50,000$ from Louisville Metro was determined over ten years ago. This amount is lumped together with the $\$ 335,000$ that Louisville Metro gives for all of the JCEO's services. The JCEO has a county coordinator whose job is to lobby to Metro Council on behalf of the 
JCEO for funding, which is how the ten community gardens continue to have financial support from Metro Louisville.

The JCEO Community Garden Council meetings allow Bethany to be transparent about where the money goes for garden upkeep. It provides opportunities for gardeners to give feedback on how money is used going forward. The January 2019 council meeting was held at the Louisville Metro Solid Waste Management Office. The gardeners discussed the annual budget and ways to raise money for the gardens. The gardeners discussed ways to get donations for the community gardens, such as offering garden tours for Metro Council persons. The JCEO gardens are in eleven different Metro Council districts. Giving tours to Metro Council persons could help raise awareness for the gardens in neighborhoods. Bethany agreed that it was a good idea and suggested that the gardens ask their Metro Council persons if Metro would fund a specific project at each garden.

Bethany provided a packet to the gardeners that showed the budget and annual expenses for all ten gardens. Major expenses include mowing, portable restrooms, garden manager stipend, tool repairs, fuel, cover crops, dumpster rental, plumbing, soil, fencing/gate, and road repair. The gardeners were shocked to find that $\$ 24,000$ of the 2018 budget went into mowing and grass maintenance. Bethany had not realized that the mowing service fee had nearly doubled since the previous year and was thankful that the gardeners caught that detail. Richard from Emerson and Carol from $7^{\text {th }}$ Street both recommended finding a new mowing service, and everyone agreed. Richard proposed that he and a few other gardeners at Emerson should mow their own grass rather than hire a mowing service because they have a push lawn mower; then Emerson would be making 
money rather than going over the budget like they had the previous year. Because of this discovery in the budget, Bethany and the gardeners agreed to have a follow-up meeting in February.

The Community Garden Council continued the discussion on lawn mowing at the follow-up meeting in February at the Golden Corral buffet. After everyone ate their fill, we relocated to a table large enough for everyone to sit around. Bethany said that she got bids for a new mowing service at $7^{\text {th }}$ Street and Russell and the JCEO will now save money. Richard informed everyone that he and other gardeners at Emerson agreed to take turns mowing the grass themselves. The discussion then changed to plot fees. The cost of plot fees increased by $\$ 5$ for the 2019 growing season. The gardeners said that they think increasing fees every two years is okay. Richard commented that Emerson has some people who can't afford the increased plot fees, but other gardeners will help them out monetarily. These discussions of funding show that JCEO gardeners have input on the budget and that their suggestions are taken seriously by the JCEO community garden manager. The high annual cost for maintenance and upkeep leaves little funding for physical resources or for projects like building a covered shelter, so gardeners must think creatively of ways to get additional funding.

An upper middle-aged black gardener at Parkland, one of the JCEO's community gardens, took me on an informal tour of the community garden in February 2019. The first thing that I noticed was that the garden is neat and well-equipped. It is surrounded by a secure metal fence. It has a large storage container and a shelter with picnic tables. All of the garden plots are raised beds of varying heights in neat rows. The gardener explained that the tall raised beds are for gardeners who need handicap accessibility. The 
low raised beds are for children to garden in. A few of the raised beds were of uneven height; the gardener told me that this is because they ran out of funding to supply the rest of the wood to build them. Parkland community garden received some funding from a local hospital to afford a few resources, including a lawn mower. They also were a recipient of Louisville Grows' community garden grant. During Community Garden Council meetings, gardeners repeatedly brought up Parkland as an ideal for all community gardens because of the garden's neatness and for the covered shelter.

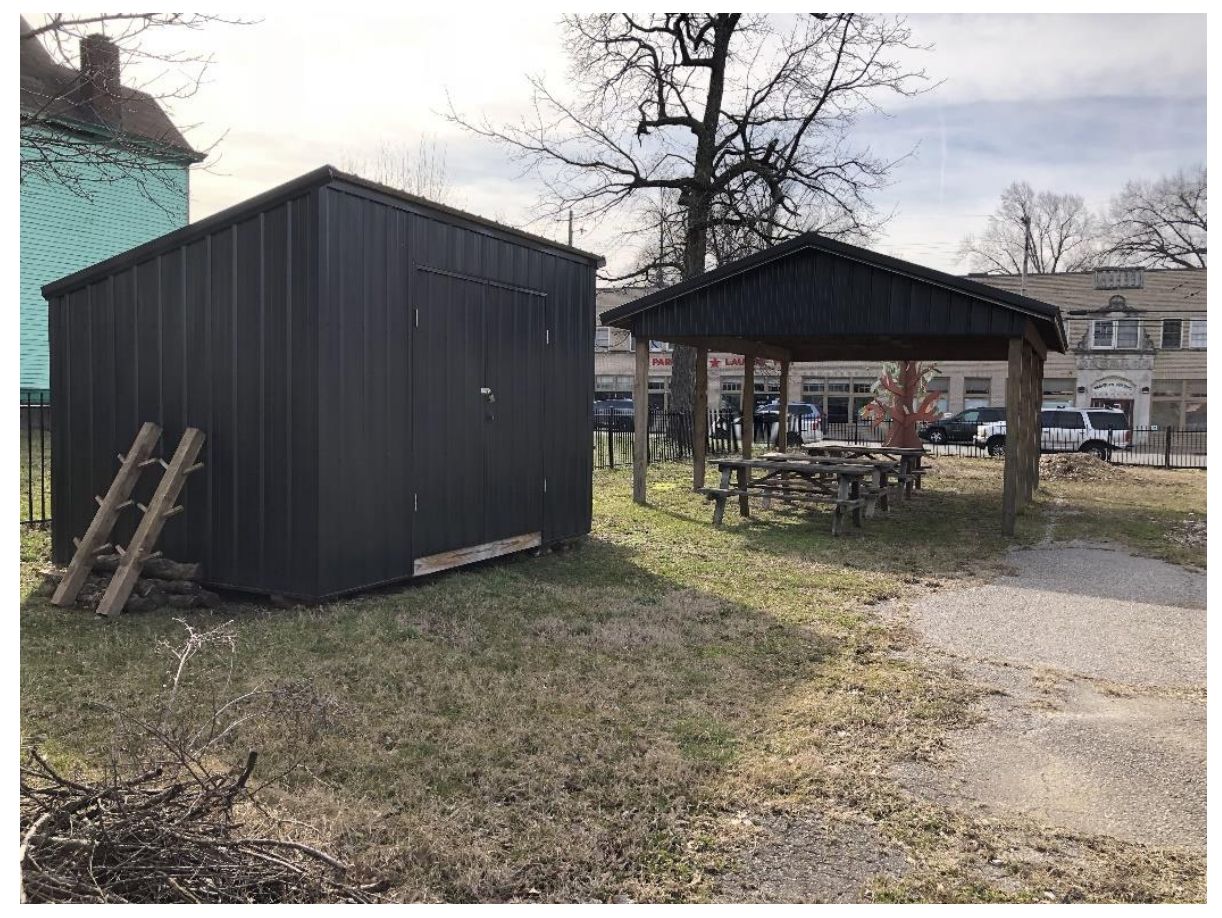

Figure 4: Parkland Community Garden's tool shed and covered shelter. February 2019.

Photo by Emily Goldstein.

At Hope Community Farm, the CSA program provides most of the funding for land upkeep. I asked Haileigh what sources of funding and support for the Farm exist outside of Louisville Grows, and she said, "I'm currently trying to find grants for the Farm, but we have a unique challenge but also blessing in the fact that we're a religious 
organization. Since we're a religious organization, some grants aren't available to us because of that affiliation. I'm still looking for grants, but a lot of our support just comes from how a Church would be supported, or any other religious ministry, which is just the donations from people." Haileigh's own salary is raised through donations from individuals because she is a local missionary. The 2018 growing season did not receive enough CSA sales to break even, but funding from Southeast Christian Church helped the Farm get through the rest of the growing season.

Funding is critical for community garden upkeep and maintenance, including in the obtaining of resources. However, the gardeners and garden managers at Louisville community gardens find creative ways to overcome this limitation, including using collaboration and resource sharing. The transparency that exists between the JCEO garden manager and gardeners through the Community Garden Council allows for many collaboration opportunities.

\section{$\underline{\text { Resources }}$}

Throughout the interview process with garden users, managers, and supporters, certain types of resources were repeatedly mentioned. Educational seminars, classes, and demonstrations were information exchange resources mentioned by four of the interviewees. Bethany mentioned classes in our interview and during the community garden manager meeting in January. She explained that garden managers can request specific topics for gardening classes during the summer and she will find a guest speaker familiar with the topic. When I interviewed Carol at $7^{\text {th }}$ Street, she gave an overview of her major roles as an assistant garden manager, and one of her tasks is to assist Bethany 
with these classes. Classes at $7^{\text {th }}$ Street have included soil management, composting, pest control, and space management. Carol said that the class on pest control was taught by someone from the University of Kentucky; she learned what kinds of plant species she should plant to bring in beneficial insects. Lilias from the Jefferson County Soil and Water Conservation District is another guest speaker for these classes. At the Community Garden Council meeting in January, gardeners mentioned seminars that Louisville Grows offers as a useful information resource.

Lilias conducts workshops at community gardens with staff members from Common Earth Gardens. Examples of workshops that Lilias has given at JCEO gardens include cover crop demonstrations, square foot gardening, and setting up rain barrels. Community garden users can approach Lilias to request workshops hosted by staff members. She also reaches out to the community gardens; in 2018 she contacted Parkland community garden to ask if they were interested in a rain barrel workshop, which they accepted. Lilias believes that an important information resource is education for gardeners to understand the importance of soil health.

Rachel Brunner from Common Earth Gardens offers trainings for refugees on a monthly basis during the growing season, based on their interests. She finds community partners and professionals to lead these trainings so that "when the garden graduates or is able to stand on its own, it doesn't only have Catholic Charities as a community partner." This allows the gardens to have a network of professionals and resources around the city that they can reach out to. Peaceful Eden community garden uses well water, which results in poor water pressure when more than one spigot is being used for the 133 plots. She arranged a drip irrigation workshop in 2018. Drip irrigation is an efficient way to use 
water that doesn't require high water pressure. "Many people have been farmers their whole lives, so they're like, 'That's not how I do it, so that's not how I'm going to do it." Instead the gardeners decided to install multiple water towers where they place massive water containers on pallet stands so that gravity gives stronger water pressure even with multiple people using them. She also arranged a pest management class in 2018, where they learned about different ways to combat pests, including bringing in beneficial insects or using pheromone traps. Gardeners can look at the community garden budget and vote on how to spend money to fight pests.

Bethany serves as an information source for gardeners, both at the JCEO community gardens and for the general population. JCEO gardeners have her phone number and can text or call her with questions pertaining to gardening, such as pest identification. Gardeners also mentioned the Internet as a source for knowledge. Carol and Don from $7^{\text {th }}$ Street and Dave from Emerson all answered that they used the Internet frequently for gardening tips.

Another major method of information exchange is through less experienced gardeners learning tips from more experienced gardeners. Dave from Emerson said that one thing he learned from another gardener was what variety of plant to grow, since some varieties grow better than others in this area. Haileigh at Hope Community Farm mentioned the value of knowledge from more experienced gardeners. Gardeners also can learn new things at the Community Garden Council meetings. These meetings provide opportunities for JCEO community gardeners to exchange information and knowledge. At the January meeting, Richard from Emerson described how he and other gardeners frequently got blight on their tomatoes. Dave from Emerson explained how he used 
copper phosphate spray on his tomato plants and had better luck. Carol from $7^{\text {th }}$ Street also gave some suggestions on how she avoids blight on her tomato plants.

Certain types of physical resources were also frequently mentioned during interviews. Two of the most frequently mentioned types of resources were compost and manure. "A lot of the manure that we use to fertilize crops are donated to Louisville Grows for public use and Louisville Grows lets us use it," Haileigh explained during the interview in November. While touring Hope Community Farm, Haileigh pointed out a large pile of horse manure near one of Louisville Grows' hoop houses and explained that Louisville Grows received it from the LMPD Mounted Patrol stabled at Iroquois Park. Horse manure is a low-quality fertilizer, but it is a free resource for many gardeners; the growers at Hope Community Farm prefer higher-quality chicken manure, which is an expensive alternative. Haileigh intends to buy chicken manure in the spring for the 2019 growing season, but the cost will limit the amount they can purchase, and they will have to rent a truck to pick it up. The plot fees at the community garden help Haileigh afford compost for the growers. Manure from Iroquois Park is also used by gardeners at the JCEO. Dave at Emerson explained that he uses it in his compost, and Carol and Don from $7^{\text {th }}$ Street also use it as a fertilizer. At the February Community Garden Council meeting, Bethany said that Iroquois Stable has less horse manure available to gardeners than they used to. This is likely because many other people use it for their gardens. Horse manure is a low-quality fertilizer, but because it is available as a free resource, that is what many community gardeners use. 


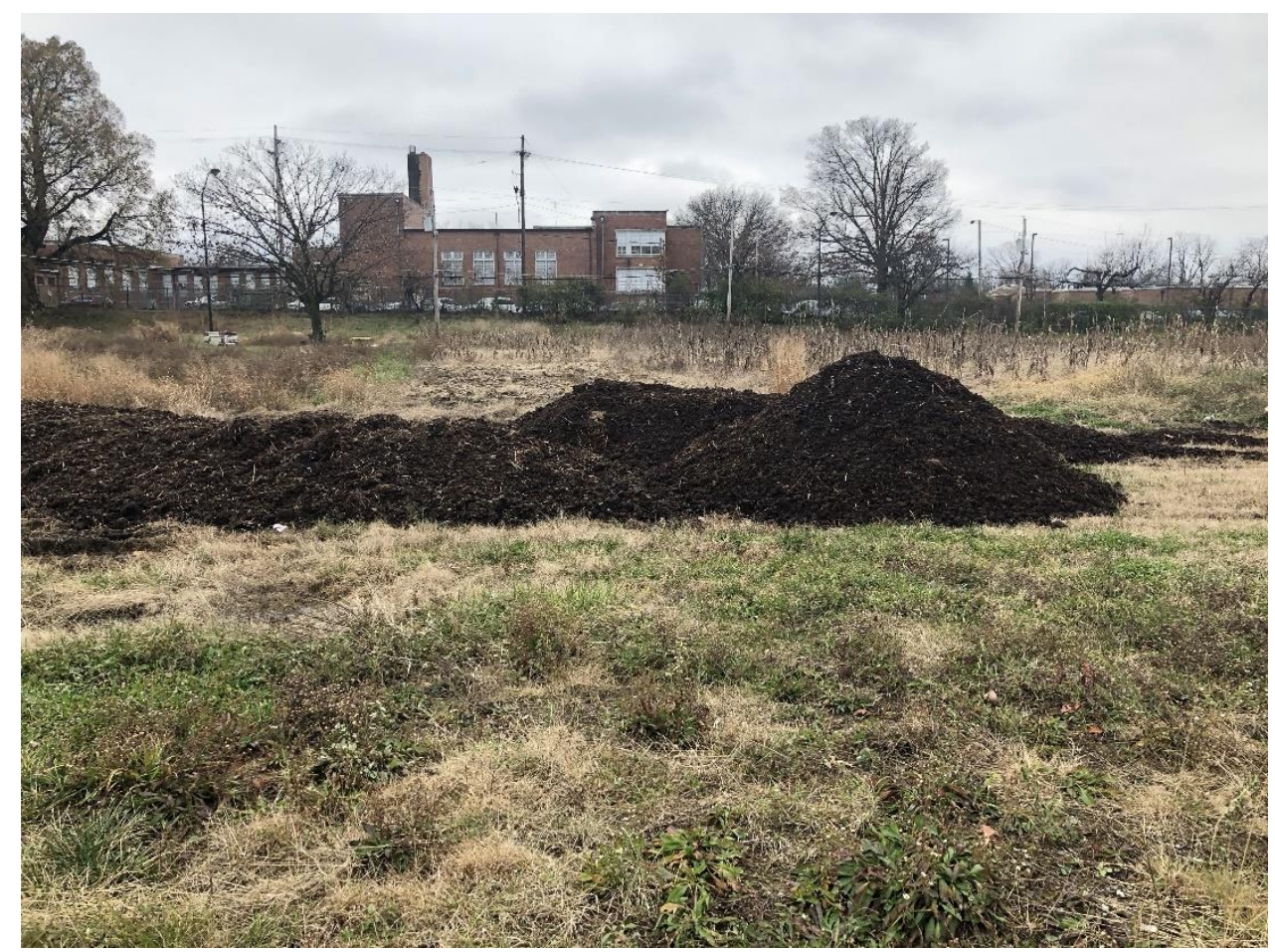

Figure 5: Manure pile at Hope Community Farm. November 2018. Photograph by Emily Goldstein.

At the community garden manager meeting on January 23, Bethany informed the garden managers that they would not have funding for compost during the coming year and there would not be any free soil available for gardeners. Gardeners can instead order bulk topsoil/compost mix from Nugent Sand Supply through the JCEO. I spoke with Dave from Emerson about resources he uses, and he told me that he makes his own compost for his garden plot using horse manure from the Mounted Police, kitchen waste, and straw from neighbors' Halloween decorations. I asked what resources could positively change Emerson community garden and he suggested a communal compost pile since people are currently individually responsible for providing their own. During the interview with Rachel she said, "They ask for compost all the time. The funding used to be able to cover that, like during the first six years of the program. The next six years 
we have not had that additional funding. And there was a lack of history sharing, to know the history of what resources were provided. Like from one coordinator to the next. Luckily as we build relationships, people will be like, 'We need compost. You used to drop off compost every year.' I've been here two years and I've just now heard this!' Now Rachel said that they can order a dump truck full of compost for about \$25 per person.

Woodchips for compost and walkways was another resource mentioned with relative frequency. Tree service companies normally must pay to dump woodchips, so dumping them at community gardens is a free alternative. Gardeners at Emerson and $7^{\text {th }}$ Street have asked for woodchips in the past and now have an overabundance of them. Richard from Emerson laughed and said that if the tree service companies did not stop donating woodchips, they would no longer have a parking lot. Indeed, at my visit to Emerson in December 2018, I immediately noticed the large pile of woodchips lined up along the fence next to the parking lot. At the February Community Garden Council meeting, Bethany mentioned that Blue Lick and Miller's Lane community gardens both need woodchips, and they can contact her to get tree service companies to donate them. 


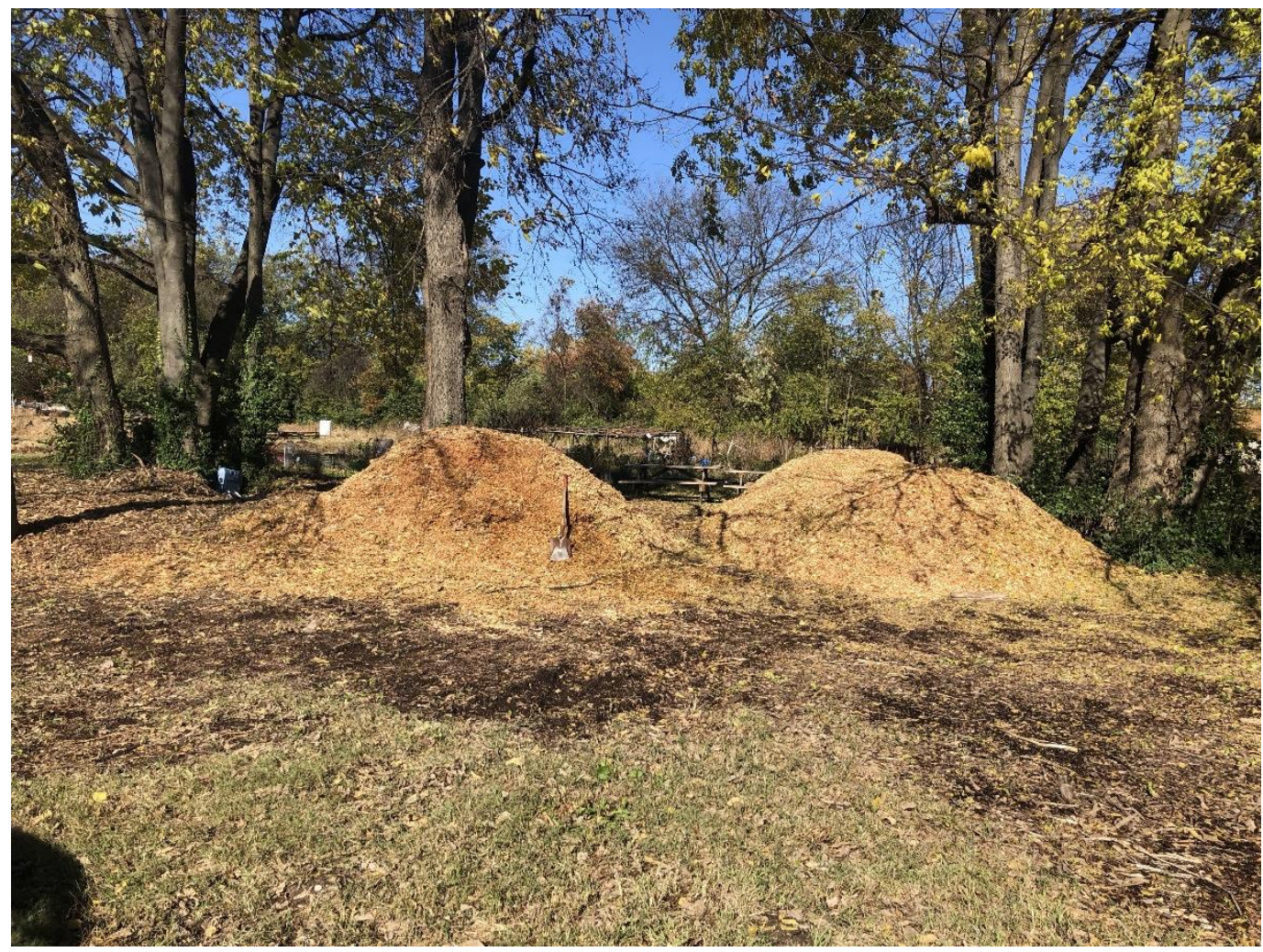

Figure 6: Woodchip piles at $7^{\text {th }}$ Street Community Garden. November 2018.

Photograph by Emily Goldstein.

Both Dave at Emerson and Lilias with the Soil and Water Conservation District mentioned water availability as the most important resource for community gardens. Lilias explained the importance of water access for community gardens. At our interview in January I spoke to Lilias about resources and she said, "Water's huge, and that's something that I think should be available for all community gardens in a low-cost or free way. It's pretty prohibitive. When I first moved to Louisville, I was working with the folks at Shippingport, which was shut down. They didn't have a water hookup, so we were getting water by collecting it from a roof." Water was brought up at all three Community Garden Council meetings that I attended for this research. During these meetings, Bethany talked about how water is shut off at garden sites not located in public 
parks over the winter but will be turned back on after the last frost, which will be in April for the 2019 growing season. The city provides water at Hope Community Farm.

Gardening tools are another resource frequently discussed. The JCEO provides most of the tools necessary for gardeners according to Carol, Don, and Dave. Carol and Don said that if the JCEO cannot provide a tool they need for their garden plots, they bring it themselves. Tools provided by the JCEO are maintained by the JCEO, but if tools are donated to a garden, the garden managers are responsible for tool maintenance. At the January community garden manager meeting, garden managers asked when gardeners could start using tillers; a company was repairing the tillers over the winter, and garden managers wanted a start date so that they could let gardeners know. Tillers can be an important tool for gardeners, but they can be expensive to buy and are easy to break if not used correctly. At the February Community Garden Council meeting, Richard said that two tillers were broken during their first week of use in 2018. During our interview, Carol and Don said that they want easy-start tillers at $7^{\text {th }}$ Street. They currently must have younger gardeners start tillers for them before they can use them.

Louisville Grows provides Hope Community Farm with most of the tools they use. Louisville Grows obtained a tool trailer in 2018 which they keep stocked with various gardening tools. A vehicle can hook it up and take it to a garden for a work day; anyone can request to use it. The annual non-financial community garden grant provides resources to grantees, including materials, services, workshops, and volunteer help. The applicants tell Louisville Grows what they need and their proposed budget in the application. When choosing applicants, they must consider how realistic it is for them to assist the gardens. If an applicant asks them to build a greenhouse or a waterline installed 
with 7,000 feet of drip irrigation, Louisville Grows would have to say no. Instead Louisville Grows typically provides infrastructure like raised garden beds. Louisville Grows will have a workday and invite volunteers to help build raised beds or a big compost bin and then have a composting workshop. According to Simon, lot of what he does at Louisville Grows for the grantees is to call local hardware stores and say, "Hey, we have a community garden that is in your neighborhood and we run this grant program to provide them with the things they need to basically have a successful community garden right around the corner from you. They really need 200 feet of hose for their rain barrels, would you be interested in donating one?" Simon told me that a lot of times the answer is yes. Local hardware stores also sometimes provide discounts for neighborhood community gardens. At the January Community Garden Council meeting, both Carol and Richard said that they have asked local hardware stores for discounts or physical resource donations with success.

Bethany informed me that if a JCEO gardener requests a specific physical resource, she will do her best to locate it for them. She could not think of a resource that a gardener requested that she denied, but it can sometimes take time because of financial restraints - the resources generally need to be free. For example, it took her a year and a half to locate free manure.

Many other physical resources were mentioned by interviewees. When Haileigh took me on a tour of Hope Community Farm at the end of November 2018, she described the areas that Louisville Grows is still responsible for. They still mow the grass and are responsible for renting the portable toilets on the property. Louisville Grows also provides volunteers to help complete large tasks on the farm. Louisville Grows supplies 
the farm with many seeds and starts from their Seeds and Starts sale; Louisville Grows also offers discounts to JCEO gardeners at their annual Seeds and Starts sale. Carol and Don at $7^{\text {th }}$ Street and Dave and Richard at Emerson obtain most of their seeds from seed companies. At the February Community Garden Council meeting, Richard from Emerson commented that he started his own seeds in his basement for the first time and that if things go well, he plans on giving some starts to other gardeners at Emerson.

The farm manager at Hope Community Farm is responsible for obtaining additional seeds and plants, as well as pest prevention products. Haileigh explained that the community garden plot fees allow her to purchase organic pesticides and seeds and starts.

Lilias with the Jefferson County Soil and Water Conservation District can provide a few reduced cost resources for community gardeners, such as rain barrels for $\$ 25$; Parkland plans on installing one soon. Lilias also runs a soil voucher program, where the cost is covered for up to two soil tests per resident. Lilias said that this program is promoted at community gardens around Louisville. She also helps provide high tunnels, which are unheated greenhouses, through the Urban High Tunnel Initiative; the USDA has a program that brings the cost down to seven percent for a high tunnel.

I visited William F. Miles community garden in November 2018. The garden is in Middletown, a neighborhood in eastern Louisville with a median household income of $\$ 71,992$ in 2015 (“Louisville Neighborhood Profiles,” 2017). The community garden is located within the Parklands of Floyds Fork. It was the first community garden I visited for my research. It was a bright day, warm enough to only need a light jacket. The garden was empty during my visit in the early afternoon. The garden is closed in by a large green 
metal fence. The garden has two access points: a gravel road via car, and a footpath. Neither gate had a lock, so I was able to walk in on the footpath. One of the first things that I noticed about the garden was that most of the plots have personal fencing like this. In my interview with Bethany, I asked her about the fencing, since I had noticed that most other community gardens did not have personal fencing. Bethany told me that William F. Miles is the only JCEO garden where most of the garden users have personal fencing. The gardeners supply the fencing themselves, it is not paid for by the JCEO. Bethany said that there are a lot of more affluent users at this garden, so they can afford to use this kind of fencing.

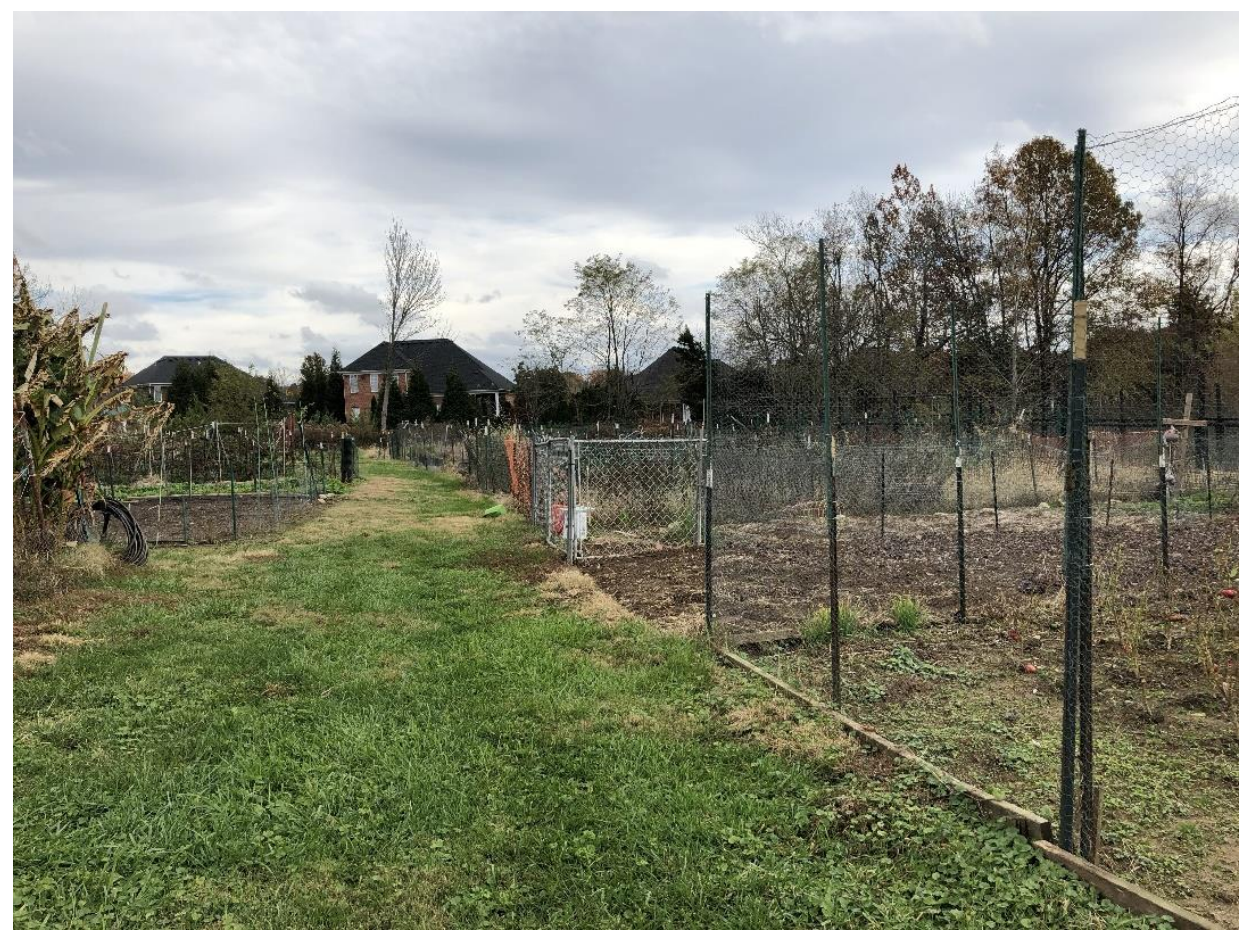

Figure 7: Plots at William F. Miles Community Garden. November 2018.

Photograph by Emily Goldstein. 
The variety of physical resources that were discussed in interviews and at meetings, and that I observed during garden tours, demonstrated how much is necessary to run a functioning community garden. Yet sharing physical resources is not the only way that gardeners overcome hardship.

A third resource that gardeners may use is shared labor. Gardeners may lend each other physical resources and share gardening tips, but another valuable resource is helping each other with physical labor. Younger gardeners start tillers for Carol and Don at $7^{\text {th }}$ Street, enabling them to use a tool that would otherwise be inaccessible for them. At Hope Community Farm, volunteer labor from Louisville Grows allows them to accomplish tasks that they otherwise would not be able to finish, such as removing dead plants from the previous growing season.

Sometimes shared labor is how community gardeners approach growing and harvesting at community gardens. Like collective gardens described by McClintock (2014), growers at Hope Community Farm work the CSA farm and some community garden plots to plant, grow, and harvest crops together. Bethany described a similar situation with Somali-American gardeners at $7^{\text {th }}$ Street. Many families rent multiple plots and then share the labor to grow and harvest crops, distributing the produce among themselves.

Resources can create major limitations for community gardens, but gardeners and garden managers find creative ways to overcome this challenge through different modes of collaboration and resource sharing. There is one type of resource that requires its own section because it has its own set of unique challenges, and that is land ownership. 


\section{Land Ownership}

A shared challenge that many Louisville community gardens face is land ownership. This is a challenge that community gardens around the United States face as well because most community gardens are on land owned by the government (Guitart, Pickering, and Byrne 2012). The JCEO community gardens are all on government property. $7^{\text {th }}$ Street and Millers Lane are on land owned by Louisville MSD. Blue Lick, Farnsley-Moremen, Emerson, and William F. Miles are on land owned by Metro Parks. Limerick is on land owned by Chapel House, a senior living facility. Russell is on land owned by City Land Bank. Parkland is on land owned by Urban Renewal. Southside is on land owned by Antioch Church.

Hope Community Farm is on land owned by Louisville Metro Housing Authority, which is leased by Louisville Grows. Haileigh explained, "if the city ever decided that they didn't want us there anymore then we would probably have to leave because we don't technically own it. We hope to own it in the future, and from what I can tell there hasn't been any movements to make the land something else." It is a possibility that the city may decide to use the land at these garden sites for projects deemed more lucrative than community gardens; this has occurred to other community gardens around the United States (Ghose and Pettygrove 2014; Guitart, Pickering, and Byrne 2012).

Any time a community garden is on land owned by someone else instead of the garden users, there is a risk of redevelopment (Cockrall-King 2012; Guitart, Pickering, and Byrne 2012). Louisville Grows established Shippingport Community Garden in 2013 on land owned by someone not personally involved with the garden. It had a strong community buy in. Simon with Louisville Grows explained to me in an email on March 
$30^{\text {th }}, 2019$, "People grew an enormous amount, had parties in the garden, built a gutter system for rain collection, and even built a large welcome sign out of local driftwood to commemorate the memory of Shippingport Island, a historic area of the neighborhood that was washed away in a flood. They also built and painted handicap accessible raised beds, a large play area for kids, and installed a dozen or so fruit trees and perennial brambles." The land owner sold the property to a rental housing developer; Louisville Grows moved the garden to a more secure location on Portland Avenue in 2017, but it has not been as successful because garden users are wary of this happening again. "The feeling of neighborhood pride in the garden just sort of drained, and those who want to get it going are finding it tough to get the same community buy in for the new, smaller, less accessible garden area," Simon explained. Though they moved the raised beds to the new community garden site, they were unable to move the trees or playground. Lilias, who worked with Shippingport in the past, believes that it is important that community gardens have the opportunity to own the land that the garden is located. What happened with Shippingport community garden is an example of how land ownership is important in the establishment and running of community gardens.

The shared challenges that Louisville community gardens face demonstrate how, despite their differences, they can use collaboration and resource sharing to overcome, or at least exist with these challenges.

\section{The Urban Political Ecology of Louisville Community Gardens}

Looking at community gardens through an UPE lens can help us understand why these shared challenges exist. As described in Chapter One, UPE works to "uncover the 
political-economic and power relations that produce current forms of urbanization, uneven urban spaces, and differentiated access to resources and services in cities" (Cornea, Véron, and Zimmer 2017:2). Looking at how micropolitics, everyday urban planning, and self-governance influence community gardens could help us understand why community gardens experience shared challenges (cf: Cornea, Véron, and Zimmer 2017; Gabriel 2014).

Urban community gardens across the United States share similar struggles with funding, participation, land, and materials (Drake and Lawson 2014). Community garden actors in Louisville use collaboration and resource sharing to navigate the shared challenges. As noted by interviewees and in ethnographic examples throughout this chapter, collaboration and resource sharing occur across multiple scales within and around gardens. It is important to understand how collaboration and resource sharing relate to scale because "attention to power asymmetries is critical for understanding networked relations within and between scales" (Neumann 2009:399). There is a hierarchy of actors involved locally within Louisville community gardens: community garden users, community garden managers, and community garden organizations. Generally, the higher up the scale, the more power the actor holds. However, the scales of collaboration and resource sharing in Louisville community gardens are not strictly hierarchical. As Neumann (2009) and Zimmerer and Bassett (2003) argue, scale should also be examined in a horizontal, or networked pattern. Ghose and Pettygrove (2014) demonstrate the importance of understanding horizontal networks of relations between actors in their research on Harambee community gardens. Horizontal scale in Louisville community gardens shows that collaboration and resource sharing can be bidirectional, 
meaning that power can be shared between actors across multiple scales. These local actors and relationships are embedded within wider scales, including at the regional, state, and federal levels. This demonstrates the importance of contextualizing scale for every study.

There are many examples of how interactions between Louisville community garden actors can be bidirectional. At the community garden user level, younger gardeners help Carol and Don start the tiller at $7^{\text {th }}$ Street. A more experienced gardener suggested varieties of plants that grow better in this area to Dave at Emerson. Horizontal scale can happen between different community gardens, such as the information exchange that occurs at the JCEO Community Garden Council meetings, like when Carol gave suggestions on how to prevent tomato blight to Richard at Emerson.

Collaboration and resource sharing occur across different organizations, such as Louisville Grows providing resources to community gardens and through the Urban Agriculture Coalition, where various urban agriculture organizations meet. They also manifest in the form of seminars and classes that the Jefferson County Soil and Water Conservation District and Common Earth Gardens provide for gardeners with the JCEO and other community gardens in Louisville.

Community gardeners and garden managers use collaboration and resource sharing to help each other. Bethany and Haileigh obtain resources requested by gardeners, such as wood chips and manure; the opposite also occurs when gardeners tell garden managers where they can locate resources, such as when a gardener told Bethany where to obtain manure. These opportunities for collaboration and resource sharing at 
multiple scales can require creativity and determination. They are one of the reasons for the success of these community gardens despite the challenges that they are up against.

Funding is easier to access for starting up community gardens but is more difficult to find for sustaining gardens. The small amount of funding for community gardens can show how government support for community gardens is often limited. Drake and Lawson (2014) describe reactions from survey respondents around the United States, including a respondent that was frustrated that the government spends billions of dollars on war and big business but could not provide $\$ 1400$ to build a well in a community garden. "By expressing frustrations, respondents also alluded to the political-economic context of government funding priorities" (249). All organizations struggle to find financial support for community gardens in Louisville. Hope Community Farm must raise its own funding through personal donations with Gate of Hope Ministries and through the sale of CSA shares because it is part of a religious organization. The JCEO receives a regular annual contribution from Louisville Metro and must raise additional funds through plot fees. The politics surrounding funding can be difficult to work around, but actors involved with Louisville community gardens find innovative ways to exist without much financial support through collaboration and resource sharing.

Resources for community gardens can be expensive or hard to come by. Drake and Lawson state, "the task of obtaining materials — water, tools, seeds, soil, and so onis an everyday issue that may lead to other problems" (2014:251). Actors involved with Louisville community garden navigate this challenge by sharing resources and collaborating to locate resources. An example of how actors collaborate to locate resources is between Bethany and gardeners, when they give suggestions on where to 
find specific resources. Information exchange is easier to come by, with free educational seminars occurring throughout the growing season at many community gardens.

Land ownership is a challenge that can be out of a gardener's control. Nearly half of the community gardens in the United States that were surveyed by Drake and Lawson (2014) are on public land. Many community gardens in Louisville are on land that is owned by the city. If the city decides to develop the land for other purposes, such as commercially, the garden would have no choice but to be removed. As I described earlier in this chapter, one way that gardeners proposed to work around this is to give tours of the community gardens to local Metro Council persons, which could show the value of the community garden for the neighborhood.

Louisville community gardens have three shared challenges: funding, resources, and land ownership. In order to overcome these challenges, community garden actors across multiple scales creatively use collaboration and resource sharing to fill in the gaps that exist because of these shared challenges. 


\section{CHAPTER IV}

Community gardens in Louisville, Kentucky use collaboration and resource sharing to navigate three shared challenges, that of: funding, resources, and land ownership. Looking at how actors involved with Louisville community gardens across multiple scales exist despite these challenges allows me to understand from my thesis data how community garden actors fill in these gaps through creative forms of collaboration and resource sharing.

Funding is a problem that all community gardens in Louisville share. There are very few opportunities to receive funding, so community garden actors must find innovative ways to find it or find ways to exist without it. One standard way of bringing in more money for gardens is by raising plot fees; however, this is not enough. Finding ways to save money on garden maintenance, such as finding more affordable lawn service companies or gardeners mowing the lawn themselves, is another way that community garden actors handle minimal funding. Community gardeners must also get creative with how they find funding sources. At the January Community Garden Council meeting, gardeners proposed asking local Metro Council members for funding to support specific garden projects. Funding is difficult to allocate but community garden actors can find ways to exist despite this challenge.

Resources are critical to community garden success, but they can be prohibitively expensive. Community garden actors have many solutions to this challenge through 
collaboration and resource sharing. Information exchange occurs in many ways.

Educational programs such as seminars occur at community garden sites around the city. Various organizations provide opportunities for these educational programs; they can be free through the JCEO, Common Earth Gardens, or the Jefferson County Soil and Water Conservation District, or have a fee through Louisville Grows. Information exchange also occurs between individuals at the gardens, during community garden meetings, or between gardeners and organization staff, such as Bethany at the JCEO or staff at Louisville Grows.

Good quality physical resources are especially challenging to obtain. The Mounted Police offer free manure to gardeners, but it is a low-quality fertilizer and other, more expensive types of manure are preferred. Tools are critical for garden success; most are provided to JCEO gardeners, but Louisville Grows has hundreds of tools that gardeners can borrow in a tool trailer. Water is a key resource, but it can be expensive or difficult to obtain for some community gardens. Peaceful Eden community garden relies on well water, which has poor water pressure. To solve this problem, gardeners are building water towers that use gravity to increase water pressure. Wood chips are used by community gardens for pathways and to create compost; gardeners figured out that if they ask a local tree service company for wood chips, the company will donate the woodchips to the gardens. Creativity and determination enable community garden actors to obtain physical resources for free.

Finally, shared labor exists in many forms throughout the community gardens. Volunteers with Louisville Grows and the JCEO offer help with physical labor, such as building raised beds or working the soil in garden plots. Some community gardeners, 
such as Somali-Americans at $7^{\text {th }}$ Street community garden and Rwandan-American gardeners at Hope Community Farm, use collective gardening to share the work and the resulting crops. Shared labor also occurs in the form of helping fellow gardeners out with tasks, such as younger gardeners starting tillers for senior gardeners at $7^{\text {th }}$ Street.

The last shared challenge that community gardens face is land ownership. There is little that many community gardens can do about this if the land they are on is owned by the government, but community gardeners proposed giving tours to Metro Council members to bring awareness about the value of the gardens in neighborhoods.

The shared challenges that community gardens face in Louisville are difficult to overcome, but community garden actors across multiple scales find ways to exist despite them. The way that they fill in gaps that these challenges cause are creative and demonstrate how much community gardeners value the gardens that they lease plots in. The shared challenges show that the community gardens are not alone in their struggles. Finding a way to unite the gardens, such as through an organization like the Urban Agriculture Coalition, could enable gardens to collaborate and share resources at an even larger scale. The more connections that community gardens have, the more opportunities for collaboration and resource sharing will manifest.

There are many possible future directions that research on Louisville community gardens could go in. During my thesis research, I was unable to interview many community gardeners. Future projects could focus on how collaboration and resource exchange are navigated from the level of community gardeners. A comparison on how collaboration and resource sharing manifest in different neighborhoods could be done, such as research on the ways that more affluent gardeners at William F. Miles in 
Middletown collaborate and share resources compared to gardeners in lower income neighborhoods like Parkland. This type of study could provide useful information on how income level influences how gardeners navigate the three shared challenges.

I could not find contacts for every active community garden in Louisville, so more in-depth research on active Louisville community gardens could be beneficial. Looking at the ways that different cultures use resources in community gardens, such as the different ways that Somali-American and Nepali-American gardeners use resources compared to American gardeners at $7^{\text {th }}$ Street, would also be an interesting direction for future research. It would also be useful to assess how race and class affect access to resources and community garden involvement.

Future research on Louisville community gardens using an UPE lens could research the history of Louisville community gardens and look at how historical, political, economic, environmental, and social factors influence how community gardens navigate the shared challenges, and why the shared challenges exist for Louisville community gardens. Future research could also look at the geographical scale of community gardens and the ways that it influences how actors navigate shared challenges. 


\section{REFERENCES}

About Brightside. (n.d.). Retrieved from https://louisvilleky.gov/government/brightside/about-brightside

About Us. (n.d.). Retrieved from https://jefferson.ca.uky.edu/content/about-us

Altieri, M.A., Camanioni, N., Cañizares, K., Murphy, C., Rosset, P., Bourque, M., and Nicholls, C.I. (1999). The greening of the "barrios": Urban agriculture for food security in Cuba. Agriculture and Human Values 16, 131-140.

Barron, J. (2016). Community gardening: cultivating subjectivities, space, and justice. Local Environment 22(9), 1142-1158.

Bernard, H.R. and Ryan, G.W. (2010). Analyzing Qualitative Data: Systematic Approaches. Sage Publications.

Bosco, E. (2017). Map of the Month: Redlining Louisville. Retrieved from https://datasmart.ash.harvard.edu/news/article/map-of-the-month-redlining$\underline{\text { louisville-1062 }}$

Bryant, R.L. (1998). Power, knowledge and political ecology in the third world: a review. Progress in Physical Geography 22(1), 79-94.

Classens, M. (2015). The nature of urban gardens: toward a political ecology of urban agriculture. Agriculture and Human Values 32, 229-239.

Cockrall-King, Jennifer. Food and the City: Urban Agriculture and the New Food Revolution. New York: Prometheus Books, 2012.

Community Gardens. (n.d.). Retrieved from https://cclou.org/common-earth-common-table/common-earthgardens/community-gardens/

Community Gardens (n.d.). Retrieved from https://jefferson.ca.uky.edu/content/community-gardens

Cornea, N.L., Véron, R., and Zimmer, A. (2017). Everyday governance and urban environments: Towards a more interdisciplinary urban political ecology. Geography Compass 11, 1-12. 
Cronon, William. (1995.) Uncommon Ground: Rethinking the Human Place in Nature. New York: W. W. Norton \& Co.

Dietsch, W.S. (2018). State-Reinforced Self-Governance of Community-Managed Open Spaces in Chicago, IL and Louisville, KY. (Unpublished master's thesis). University of Louisville, Louisville, KY.

Drake, L. and Lawson, L.J. (2015). Results of a US and Canada community garden survey: shared challenges in garden management amid diverse geographical and organizational contexts. Agriculture and Human Values 32(2), 241-254.

Draper, C. and Freedman, D. (2010). Review and Analysis of the Benefits, Purposes, and Motivations Associated with Community Gardening in the United States. Journal of Community Practice 18(4), 458-492.

Firth, C., Maye, D., and Pearson, D. (2011). Developing "community" in community gardens. Local Environment 16(6), 555-568.

Gabriel, N. (2014). Urban Political Ecology: Environmental Imaginary, Governance, and the Non-Human. Geography Compass 8(1), 38-48.

Ghose, R. and Pettygrove, M. (2014). Actors and networks in urban community garden development. Geoforum 53, 93-103.

Glover, T.D., Shinew, K.J., and Parry, D.C. (2005). Association, Sociability, and Civic Culture: the Democratic Effect of Community Gardening. Leisure Sciences 27, 75-92.

Gonzalez, C.G. (2003). Seasons of Resistance: Sustainable Agriculture and Food Security in Cuba. Tulane Environmental Law Journal 16, 685-732.

Greenberg, J.B. and Park, T.K. (1994). Political Ecology. Journal of Political Ecology 1, $1-12$.

Grow With Us. (n.d.). Retrieved from https://foodinneighborhoods.org/grow/

Guitart, D., Pickering, C., and Byrne, J. (2012). Past results and future directions of urban community gardens research. Urban Forestry \& Urban Greening 11, 364-373.

Hanna, A.K. and Pikai, O. (2000). Rethinking Urban Poverty: A Look at Community Gardens. Bulletin of Science, Technology \& Society, 20(3), 207-216.

Heynen, N. (2017). Urban Political Ecology [Abstract]. International Encyclopedia of 
Geography: People, the Earth, Environment and Technology. Richardson, D., Castree, N., Goodchild, M.F., Kobayashi, A., Liu, W., \& Marston, R.A. (Eds.). doi:10.1002/9781118786352.wbieg1110

Heynen, N., Kaika, M., \& Swyngedouw, E. (Eds). (2006). In the Nature of Cities: Urban political ecology and the politics of urban metabolism. New York, NY:

Routledge.

Hohenthal, J., Räsänen, M., \& Minoia, P. (2018). Political ecology of asymmetric ecological knowledges: diverging views on the eucalyptus-water nexus in the Taita Hills, Kenya. Journal of Political Ecology 25, 1-19.

Horst, M., McClintock, N., and Hoey, L. (2017). The Intersection of Planning, Urban Agriculture, and Food Justice. Journal of the American Planning Association 83(3), 277-295

Johnston, B.R. (2003). The Political Ecology of Water: An Introduction. Capitalism Nature Socialism 14(3), 73-90.

Lawrence, B.L. (2005). Nature in Fragments: The Legacy of Sprawl. Johnson, E.A., \& Klemens, M.W. (Eds). New York, NY: Columbia University Press.

Loosemore, B. (2019a, January 10). In 30 seconds: What you should know about food deserts in

Louisville. The Courier Journal. Retrieved from https://www.courierjournal.com/

Loosemore, B. (2019b, January 10). Sorry, we're closed: How everyone is hurt when grocery stores shut down. The Courier Journal. Retrieved from https://www.courier-journal.com/

Louisville, KY History. (n.d.). Retrieved from https://www.gotolouisville.com/things-to-do/history/

Louiville Neighborhood Profiles. (2017). Retrieved from http://ksdc.louisville.edu/research/sponsored_projects/louisville-neighborhoodprofiles/

Marris, Emma. (2011). Rambunctious Garden: Saving Nature in a Post-Wild World. New York: Bloomsbury Press.

McClintock, N. (2010). Why Farm the City? Theorizing Urban Agriculture through a Lens of Metabolic Rift. Cambridge Journal of Regions, Economy and Society 3(2), 191-207.

McClintock, N. (2014). Radical, reformist, and garden-variety neoliberal: coming to 
terms with urban agriculture's contradictions. Local Environment 19(2), 147-171.

Messina, W.A., Jr. (1999). Agricultural Reform in Cuba: Implications for Agricultural Production, Markets and Trade. Cuba in Transition, 433-442.

Milbourne, P. (2012). Everyday (in)justices and ordinary environmentalisms: community gardening in disadvantaged urban neighbourhoods. Local Environment 17(9), 943-957.

Mission, Vision, and Values. (n.d.). Retrieved from https://newroots.org/mission-vision-and-values/

Mok, H., Williamson, V.G., Grove, J.R., Burry, K., Barker, S.F., and Hamilton, A.J. (2014). Strawberry fields forever? Urban agriculture in developed countries: a review. Agronomy For Sustainable Development 34, 21-43.

Montgomery, V.A. (2016). A Qualitative Analysis of Communality in Louisville Community Gardens. (Unpublished master's thesis). University of Louisville, Louisville, KY.

Murchison, J.M. (2010). Ethnography essentials: designing, conducting, and presenting your research. San Francisco: Jossey-Bass.

Neumann, R.P. (2009). Political ecology: theorizing scale. Progress in Human Geography 33(3), 398-406

Nord, M., Andrews, M., and Carlson, S. (2005). Household food security in the United States. Washington: USDA Economic Research Service. Report No.: ERR-29. Retrieved from https://www.ers.usda.gov/webdocs/publications/45655/29206_err29_002.pdf?v=4 1334

Pearsall, H., Gachuz, S., Sosa, M.R., Schmook, B., van der Wal, H., \& Gracia, M.A. (2016). Urban Community Garden Agrodiversity and Cultural Identity in Philadelphia, Pennsylvania, U.S. Geographical Review 107(3), 476-495.

Poulsen, M.N., Hulland, K.R.S., Gulas, C.A., Pham, H., Dalglish, S.L., Wilkinson, R.K., and Winch, P.J. (2014). Growing an Urban Oasis: A Qualitative Study of the Perceived Benefits of Community Gardening in Baltimore, Maryland. Culture, Agriculture, Food, and Environment 36(2), 69-82.

Redlining Louisville: The Racist Origins of City Planning and Real Estate. (n.d.). Retrieved from http://www.arcgis.com/apps/MapSeries/index.html?appid=a73ce5ba85ce4c3f80d $\underline{365 \mathrm{ab} 1 \mathrm{ff} 89010}$ 
Robben, A.C.G.M. \& Sluka, J.A. (Eds.) (2012). Ethnographic Fieldwork: An Anthropological Reader. 2nd ed. Wiley-Blackwell.

Saldaña, J. (2009). The Coding Manual for Qualitative Researchers. Thousand Oaks, CA: Sage Publications.

Sheridan, T.E. (1995). Arizona: The Political Ecology of a Desert State. Journal of Political Ecology 2, 41-57.

Short, T. (2016). La Minga as a Model of Food Justice? A Thesis on the Motivations and Practices of Immigrant and Native-Citizen Growers at La Minga Cooperative Farm in Prospect, KY. (Unpublished master's thesis). University of Louisville, Louisville, KY.

Smith, L. (2001). The Urban Political Ecology of Water in Cape Town. Urban Forum 12(2), 204-224.

Smith, C.M. and Kurtz, H.E. (2003). Community Gardens and Politics of Scale in New York City. The Geographical Review 93(2), 193-212.

Swyngedouw, E. and Heynen, N.C. (2003). Urban Political Ecology, Justice and the Politics of Scale. Antipode: A Radical Journal of Geography 35(5), 898-918.

Taylor, J.R., and Lovell, S.T. (2012). Mapping public and private spaces of urban agriculture in Chicago through the analysis of high-resolution aerial images in Google Earth. Landscape and Urban Planning 108(1), 57-70.

The People's Garden. (n.d.). Retrieved from http://www.louisvillegrows.org/urban-agriculture/the-peoples-garden/

Urban Agriculture Map. (n.d.). Retrieved April 1, 2019 from https://foodinneighborhoods.org/grow/map/

U.S. Census Bureau: QuickFacts. (n.d.). Retrieved March 12, 2019 from https://www.census.gov/quickfacts/fact/table/louisvillejeffersoncountybalanceken tucky/AGE295217

Who We Are. (n.d.). Retrieved from https://kentuckydoubledollars.org/who-we-are/

Winne, Mark. Closing the Food Gap: Resetting the Table in the Land of Plenty. Boston, MA: Beacon Press Books, 2008.

Zezza, A. and Tasciotti, L. (2010). Urban agriculture, poverty, and food security: Empirical evidence from a sample of developing countries. Food Policy 35, $265-$ 273. 
Zimmerer, K.S. and Basset, T.J. (2003). Approaching Political Ecology: Society, Nature, and Scale in Human-Environment Studies. In K.S. Zimmerer and T.J. Basset (Eds). Political Ecology: An Integrative Approach to Geography and

Environment-Development Studies (pp. 1-25). New York, NY: Guilford Press. 


\section{CURRICULUM VITA}

NAME: $\quad$ Emily Goldstein

ADDRESS: 1607 Washington Blvd

Louisville, Kentucky 40242

DOB: $\quad$ Louisville, Kentucky - November 21, 1990

EDUCATION

\& TRAINING: $\quad$ B.A., Anthropology

University of Louisville

2009-2014

AWARDS: Dimensions of Political Ecology Poster Competition Winner 2019

WLKY Bell Award Winner

2012

Women Leading Kentucky Achievement Award 2011

Nicodemus Wilderness Project National Award 2011

National Fellow of the Platinum Torch Honor Society 2010 